\title{
Anti-clockwise pressure-temperature paths record Variscan upper-plate exhumation: example from micaschists of the Porto Vecchio region, Corsica
}

\begin{tabular}{|r|l|}
\hline Journal: & Journal of Metamorphic Geology \\
\hline Manuscript ID & JMG-17-0010 \\
\hline Manuscript Type: & Original Article \\
\hline Date Submitted by the Author: & $18-$ Feb-2017 \\
\hline Complete List of Authors: & $\begin{array}{l}\text { Massonne, Hans-Joachim; Universität Stuttgart, Institut für Mineralogie } \\
\text { und Kristallchemie } \\
\text { Cruciani, Gabriele; Università degli Studi di Cagliari, Dipartimento di } \\
\text { Scienze della Terra; } \\
\text { Franceschelli, Marcello; Università degli Studi di Cagliari, Dipartimento di } \\
\text { Scienze della Terra } \\
\text { Musumeci, Giovanni; Universita degli Studi di Pisa, Dipartimento di Scienze } \\
\text { della Terra }\end{array}$ \\
\hline Keywords: & \begin{tabular}{l} 
Corsica, garnet, geochronology, Variscan orogeny, anticlockwise P-T path \\
\hline
\end{tabular} \\
\hline
\end{tabular}


$1 \quad$ Anti-clockwise pressure-temperature paths record Variscan upper-

2 plate exhumation: example from micaschists of the Porto Vecchio

4

\section{Hans-Joachim Massonne ${ }^{1}$, Gabriele Cruciani ${ }^{2}$, Marcello Francheschelli ${ }^{2}$, Giovanni Musumeci ${ }^{3}$}

\section{(}

8

9

10
(6)

Short title: Variscan micaschists of Corsica

8

9

20 Sur

References:

Figures:

Tables:

${ }^{1}$ Institut für Mineralogie und Kristallchemie, Universität Stuttgart, Germany

${ }^{2}$ Dipartimento di Scienze Chimiche e Geologiche, Università di Cagliari, Italy

${ }^{3}$ Dipartimento di Scienze della Terra, Università di Pisa, Italy
corresponding author: H.-J. Massonne, Tel.: +49-711-68581225, Fax: +49-711-68581222, * e-mail: h- j.massonne@mineralogie.uni-stuttgart.de

Summary:

282 words 7483 words (British spelling)

65

11 (colour in print for Figs 1-4, 6, 9-11)

4 


\section{ABSTRACT}

We studied garnet-bearing micaschists which were sampled $3 \mathrm{~km}$ east and $15 \mathrm{~km}$ northeast of Porto Vecchio, south-eastern Corsica. After a careful investigation of the textural relations and compositions of minerals, especially of zoned garnet, we reconstructed a pressuretemperature $(P-T)$ path using contoured $P-T$ pseudosections. U-Th-Pb dating of monazite in the micaschists was undertaken with the electron microprobe. The micaschists from both localities formed along similar anti-clockwise $P-T$ paths. The prograde branch of these paths starts at $3 \mathrm{kbar}$ close to $600^{\circ} \mathrm{C}$ in the $P$-T field of sillimanite and reaches peak conditions at 7 kbar and temperatures of $600\left(15 \mathrm{~km} \mathrm{NE}\right.$ of Porto Vecchio) to $630{ }^{\circ} \mathrm{C}(3 \mathrm{~km} \mathrm{E}$ of Porto Vecchio). The metamorphism at peak $P-T$ conditions happened around $340 \mathrm{Ma}$ based on low $\mathrm{Y}\left(<0.65 \mathrm{wt} \% \mathrm{Y}_{2} \mathrm{O}_{3}\right)$ monazite. Ages of monazite with high $\mathrm{Y}$ contents $\left(>2 \mathrm{wt} \% \mathrm{Y}_{2} \mathrm{O}_{3}\right)$, which probably have formed before garnet, scatter around $362 \mathrm{Ma}$. The retrograde branch of the $P-T$ paths passes through 4 kbar at about $550^{\circ} \mathrm{C}$. We conclude that the studied micaschists belong to a common metasedimentary sequence, which extends over the Porto Vecchio region and is separated from other metamorphic rock sequences in the north and the south by major tectonic boundaries. This sequence had experienced peak pressures which are lower than those determined for metamorphic rocks, such as micaschist and gneiss, from north-eastern Sardinia. At present, we favour a continent-continent collisional scenario with the studied metasedimentary sequence buried during the collisional event as part of the upper plate. The contemporaneous high-pressure metamorphic rocks from NE Sardinia were part of the upper portion of the lower plate. The addressed rocks from both plates were exhumed in an exhumation channel.

KEYWORDS: Corsica, garnet, geochronology, Variscan orogeny, anticlockwise P-T path 


\section{INTRODUCTION}

The understanding of metamorphic processes in the Earth's crust requires detailed studies of rock units. These studies should combine geochronological data, the derivation of the pressure $(P)$ - temperature $(T)$ evolution (= mass flow), and the observation of textural relations (= deformation, melting, etc.) on the mesoscopic and microscopic scale. Recent works, that have followed the above requirements, for instance, in studying metamorphic rock units of the Himalayas, come to the conclusion that the lowermost (nappe) units, which are currently exposed in this orogen, (1) are of Indian affinity, (2) have been exhumed by several relatively discrete, ductile shear-zones, which were active during significantly different times (Middle Eocene to Miocene), and (3) were partially molten enhancing their exhumation (e.g., Liu et al., 2011; Wang et al., 2013; Iaccarino et al., 2015; Carosi et al., 2017 and references therein). The mass flow of the rocks from these (Indian) units can be characterized by clockwise $P-T$ loops and back-thrusting near the collisional front although the Indian crust is the lower plate in the corresponding continent-continent collision scenario confirmed by geophysical data (e.g., Zhou \& Murphy, 2005).

The aforementioned Himalayas are an orogenic belt with still ongoing continentcontinent collision and, thus, active exhumation of the nappe stack at the collisional front. It is easily conceivable that after cessation of the collision this nappe stack will be broadly eroded and other collisional features exposed in a denuded orogen then. This situation exists, for instance, in the Variscan orogen since Permian times according to the evolution of sedimentary cover sequences. Consequently, it is reasonable to study collisional processes, deeply located in orogenic crust, in the (Carboniferous) Variscan basement instead of that in the Himalayas. Integrated studies considering geochronology, metamorphic petrology, and structural geology, as suggested above, were already undertaken by various authors in the Variscan basement (e.g., Giacomini et al., 2008; Cruciani et al., 2016, in the here addressed 
Corsica-Sardinia block). However, geodynamic conclusions, resulting from the work in this basement, suffer from the unclear location of the former collisional front and geometry of the colliding plates which is easy to reconstruct for an ongoing continent-continent collision as in the Himalayas.

In the north-eastern part of the Variscan Corsica-Sardinia block, high-pressure (HP: $>10$ kbar) metamorphic rocks occur (see below) that reflect collisional processes affecting the upper portion of the downgoing continental plate. In this paper, we report about metamorphic rocks which are part of the upper plate, but are now in tectonic contact to the HP ones from the lower plate. The studied rocks are characterized by an anti-clockwise $P-T$ path which could be typical for the lower portion of the upper plate exposed in denuded orogens.

\section{GEOLOGICAL SETTING}

\section{General aspects}

The Corsica-Sardinia block represents a major area of exposed Variscan crust in southwestern to central Europe (Faure et al., 2014; Rossi et al., 2009). This area is traditionally subdivided into the Inner Zone (or Axial Zone), exposed in northern Sardinia and Corsica, and the Internal and External Nappe zones of central to southern Sardinia (Ghezzo \& Orsini, 1982; Carmignani et al., 1994; 2001 and references therein). Late Carboniferous batholiths (Rossi \& Cocherie, 1991; Paquette et al., 2003) of various granitoids dominate the Inner Zone but minor coherently exposed areas of medium- to high-grade metamorphic rocks occur as well (e.g. Ménot \& Orsini, 1990; Fig. 1). Sardinian metamorphic rocks north of the PosadaAsinara line (PAL), a major strike-slip fault in northern Sardinia, are characterized by HP metamorphism: (1) eclogite bodies, enveloped by gneisses, occur in north-eastern Sardinia (Cortesogno et al., 2004; Cruciani et al., 2011, 2012, 2015; Franceschelli et al., 2007; Giacomini et al., 2005); (2) the country rocks, various types of gneisses and migmatites 
101 frequently with some garnet, experienced pressures slightly in excess of $10 \mathrm{kbar}$ (Cruciani et 102 al., 2008a, b; Massonne et al., 2013); (3) the peak pressure recorded by micaschists can even 103 be as high as $17 \mathrm{kbar}$ (Cruciani et al., 2013). The occurrences of HP metamorphic rocks

104

extend to south-eastern Corsica where granulites are exposed which had experienced pressures as high as $19 \mathrm{kbar}$ (Giacomini et al., 2008).

$\mathrm{U}-\mathrm{Pb}$ zircon ages obtained from the cited HP rocks were related to HP (or hightemperature) metamorphism as follows: Early Devonian ages were reported by Cortesogno et al. (2004: $403 \pm 4 \mathrm{Ma}$ ) and by Palmeri et al. (2004: $400 \pm 10 \mathrm{Ma}$ ). Late Devonian to Early Carboniferous ages were given by Giacomini et al. (2005: $352 \pm 3 \mathrm{Ma}$; 2008: $361 \pm 3 \mathrm{Ma}$ ). These authors suggested a long-lasting exhumation of the HP rocks from south-eastern Corsica in Early Carboniferous times (c. 360-330 Ma) accompanied by a deformational event (D2 according to Giacomini et al., 2008). Later on (315-325 Ma, D3) shear zones such as the PAL became active (Di Vincenzo et al., 2004; Carosi et al., 2012). These shear zones are widespread in the Corsica-Sardinia block (Elter et al., 1990, 1999) and characterized by an orogen-parallel, dextral transpressive regime (Carosi \& Oggiano, 2002; Carosi \& Palmeri, 2002; Iacopini et al., 2008).

\section{Sampling areas}

In the sampling area east of Porto Vecchio (Fig. 1a,b), the Palaeozoic basement mainly consists of Late Carboniferous granodiorite and syenogranite of the Corsica-Sardinia batholith (Rossi \& Cocherie, 1991). A large slice of amphibolite-facies metamorphic rocks (Porto Vecchio Unit) is embedded in these magmatic rocks (Rouire et al., 1993). The Porto Vecchio Unit is a sequence of metasediments and orthogneisses characterized by upright (steeply dipping) NW-striking lithological boundaries and metamorphic foliations. We sampled these rocks along the Route de Phare (Fig. 1b). In this work, we focus on the two-mica paragneiss which includes decimetre to metre thick layers of garnet-bearing micaschist. The fine- to 
medium-grained paragneiss consists of quartzofeldspathic layers alternating with thin biotitemuscovite-rich layers marked by the diffuse presence of muscovite porphyroblasts. The micaschist, such as our sample Cors $15 \mathrm{G}$, is characterized by biotite-rich layers with diffuse occurrence of millimetre-sized garnet porphyroblasts that also occur in micaceous layers within the paragneiss. This metasedimentary sequence is characterized by two sets of foliation with a dominant well-developed mylonitic fabric at the outcrop scale. This fabric is due to the activity of a major shear zone, the Porto Vecchio Shear Zone (PVSZ, Fig. 1b).

Adjacent to the micaschist-paragneiss sequence to the north a mylonitic orthogneiss occurs which is well exposed along the coast of the Punta Chiappa area. This rock is characterized by centimetre to decimetre thick quartzofeldspatic-rich layers, showing a transition from decimetre to metre thick domains with augen fabric, and alternating biotiterich layers. According to our observation, a N $110^{\circ}-130^{\circ}$ E steeply dipping mylonitic foliation is present. A dextral sense of shear (Fig. 1b) can be derived from asymmetric porphyroclasts and SC-type shear bands of decimetre to centimetre size. A previous older gneissic foliation is recognizable in the less deformed domains. This rock fabric, which relates to the activity of the PVSZ, is compatible with that reported by Giacomini et al. (2008).

The southern part of the Fautea-Solenzara Unit crops out in our sampling area $\sim 15 \mathrm{~km}$ north-east of Porto Vecchio (Fig. 2). This unit is made up of granulite, migmatite, gneiss, and micaschist (Rouire et al., 1993). The latter two rock types dominate at and near Punta di Fautea and suggest a metasedimentary sequence also because of the interlayering of whitemica and quartz-rich rocks. The finely foliated rocks there show a clear folding of the foliation planes (Fig. 2b). Especially in gneiss stretched and asymmetric quartz-feldspar porphyroclasts occur pointing to shearing as well. In micaschist a diffuse occurrence of mmsized garnet, frequently in layers of mm-sized biotite and potassic white-mica, is obvious (samples Cors16 and Cors17). Occasionally, cm-sized garnet appears (Fig. 2c). 


\section{ANALYTICAL PROCEDURES}

154 In order to analyze the three micaschist samples Cors15G, Cors16, and Cors17 for major elements, finely ground rock powder was produced from a small rock block, c. 20-30 g, which was previously used for the preparation of polished thin-sections. A glass disk was prepared by fusing rock powder with Spectromelt ${ }^{\circ}$ (ratio 1:6). This disk was analyzed with a PHILIPS PW2400 X-ray fluorescence (XRF) spectrometer with wave-length dispersive (WD) system. Three standards were measured before the samples to verify that the calibration of the instrument was still alright.

For the chemical analysis of minerals in our samples a CAMECA SX100 electron microprobe (EMP) with 5 WD systems was employed. The conditions for a c. 2 minutes Massonne (2012). For the calculation of structural formulae of minerals and the content of molar fractions of mineral components from EMP analyses, the computer programme CALCMIN (Brandelik, 2009) was used.

For dating of monazite with the EMP, Si, P, S, Ca, Y, La, Ce, Pr, Nd, Sm, Eu, Gd, Pb (for peak and background altogether c. 20 min. counting time), Th, and U were analyzed following the approach of Massonne et al. (2012). This procedure yields a good match with more precise mass spectrometric methods for dating of Tertiary to Palaeozoic monazite (see Massonne, 2016a; Waizenhöfer \& Massonne, 2017). The $2 \sigma$ uncertainty of our dating results related to a single analysis was calculated by error propagation of the $2 \sigma$ errors of the counting rates of the peak and background intensities of the relevant elements. Since many monazite analyses yielded $\mathrm{ThO}_{2}$ contents between 4 and $5 \mathrm{wt} \%$ and $\mathrm{UO}_{2}$ contents close to 1 wt $\%$, a $1 \sigma$ error between 6 and 7 Ma often resulted for the single analysis. The determination of the monazite ages were undertaken with the CALCMIN programme (Brandelik, 2009). 
177 Errors were calculated with the MINCALC-V5 software programme (Bernhardt, 2007). The

178 Isoplot programme of Ludwig (1999) was used to calculate average ages and errors of 179 monazite populations.

180 To recognize zoning patterns of garnet, potassic white mica, and monazite, five 181 element concentration maps for major and minor elements were prepared simultaneously by 182 step-wise movement of a thin section under the electron beam of the EMP and subsequent computer-aided evaluation. For the mapping, counting times per step of $100 \mathrm{~ms}$ were applied. The electric current was either $50 \mathrm{nA}$ (monazite, garnet) or $25 \mathrm{nA}$ (mica).

\section{MINERAL TEXTURES AND COMPOSITIONS}

The studied micaschists (Cors15G, Cors16, Cors17) were taken from rock portions without evidence of partial melting. The major and minor minerals in these rocks are quartz, white mica, biotite, plagioclase, garnet, and sillimanite. Accessory phases are apatite, monazite, zircon, opaque phases (mainly ilmenite), and K-feldspar (found only in Cors 17).

Micas form two main generations which both are hardly oriented but enriched in layers with thicknesses less than $1 \mathrm{~cm}$. The older generation is characterized by $\mathrm{mm}$-sized, thick flakes (Fig. 3a) which can be bent and kinked (Fig. 3c). The younger main generation, typically showing undeformed grains with sizes around $0.1 \mathrm{~mm}$, frequently surrounds these flakes (Fig. 3a). Aggregates of very fine-grained (frequently $<10 \mu \mathrm{m}$ ) micas (third generation), which are mostly potassic white-mica, occur (Fig. 3f). Occasionally, elongated clusters of sillimanite (fibrolite) are in the centre of these mica aggregates (Fig. 3e). These clusters can be bent (Fig. 3e).

Layers enriched in quartz and plagioclase occur. Larger plagioclase grains (Fig. 3d) can be partially surrounded by significantly smaller grains of this phase. Originally existing larger quartz grains, experienced, however, a complete grain size reduction. 
Most garnet grains show diameters less than $0.5 \mathrm{~mm}$ (Fig. 3d). These grains are well

203

204

205

206

207 preserved in contrast to mm-sized garnet in sample Cors15G, which are broadly decomposed. The decomposition products resemble pinite (Fig. 3b). However, garnet relics in the "pinite" aggregate clearly prove that it formed from this mineral instead of cordierite. True inclusions in garnet are quartz and ilmenite. In case of some micas, they can also be decomposition products instead of inclusion phases.

Mineral abundances were determined counting "pinite" and aggregates of very finegrained micas as garnet and sillimanite, respectively. Garnet modal contents in the three samples are about 2 vol\%. Sillimanite contents are different (c. 1-2\% in Cors $15 \mathrm{G}$ and Cors $17,10 \%$ in Cors16). Mica contents are 40-45, 45-48, and $35 \%$ in samples Cors $15 \mathrm{G}$, Cors16, and Cors17, respectively. Potassic white mica predominates. Ratios of white to dark mica are between 4:1 (Cors16) and 2:1 (Cors17). Quartz contents are between 40 (Cors16) and $50 \%$. Plagioclase modal contents amount to $10-15 \%$ in samples Cors $15 \mathrm{G}$ and Cors 17 . Sample Cors 16 contains only a few percent plagioclase. Ilmenite contents are around $0.5 \%$.

A compositional variability of garnet in samples Cors $15 \mathrm{G}$ and Cors 17 is discernable in the elemental maps of Figure 4. Results of EMP spot analyses of the diverse garnet domains are shown in Figure 5 and Table 1. The composition of the garnet core (with idiomorphic shape in Fig. 4) in sample Cors 17 is, in terms of molar fractions, $\mathrm{Alm}_{0.735} \mathrm{Gro}_{0.04} \mathrm{Pyr}_{0.125} \mathrm{Spe}_{0.10}$ (with components Alm: almandine, Gro: grossular (+andradite), Pyr: pyrope, Spe: spessartine). The mantle tends to higher spessartine and lower pyrope and grossular contents. The composition of the garnet rim is $\mathrm{Alm}_{0.725} \mathrm{Gro}_{0.025} \mathrm{Pyr}_{0.10} \mathrm{Spe}_{0.15}$. The mm-sized garnet in sample Cors15G, although corroded, has extended cores with a prograde zonation (inner core region: $\mathrm{Alm}_{0.70} \mathrm{Gro}_{0.04} \mathrm{Pyr}_{0.145} \mathrm{Spe}_{0.115}$, outer core region: $\mathrm{Alm}_{0.73} \mathrm{Gro}_{0.04} \mathrm{Pyr}_{0.16} \mathrm{Spe}_{0.07}$ ), i.e. decreasing $\mathrm{Mn}$ and slightly increasing $\mathrm{Mg}$ contents. A poorly defined mantle $\left(\mathrm{Alm}_{0.75} \mathrm{Gro}_{0.04} \mathrm{Pyr}_{0.15} \mathrm{Spe}_{0.06}\right)$ surrounds this core. After significant corrosion of such large garnets, a Mn-rich garnet rim $\left(\mathrm{Alm}_{0.715} \mathrm{Gro}_{0.045} \mathrm{Pyr}_{0.06} \mathrm{Spe}_{0.18}\right)$ grew around the remaining 
fragments (Figs. 4 and 5, Table 1).

Potassic white-mica in the three studied samples is exclusively muscovite. However, the texturally different muscovite generations can be compositionally distinguished (Figs. 6 and 7, Table 2). The oldest generation (thick flakes) contains considerable amounts of Ti (around $1 \mathrm{wt} \% \mathrm{TiO}_{2}$ ). Contents of $\mathrm{Si}$ per double formula unit (pdfu) slightly scatter around 6.08 in Cors $15 \mathrm{G}$ and 6.12 in Cors17. In the elemental maps of Figure 6 domains with somewhat higher $\mathrm{Ti}$ (and $\mathrm{Mg}$ according to the substitution $2 \mathrm{Al}=\mathrm{Mg}+\mathrm{Ti}$ ) or $\mathrm{Na}$ are discernable. The younger mica generation (smaller flakes around the thick flakes), as worked out for Cors17 (Fig. 7), is characterized by lower Ti contents $\left(<0.4 \mathrm{wt} \% \mathrm{TiO}_{2}\right)$ and somewhat higher Si contents (around 6.17 Si pdfu) compared to the oldest white mica generation. In Cors15G, slightly larger grains in the aggregates of very fine-grained micas could be analyzed. These grains are characterized by very low Ti contents and Si around 6.30 pdfu. The contents of $\mathrm{Mg}$ and Fe are relatively high due to the Tschermak's substitution ( $\mathrm{Si}+$ $\left.\mathrm{Mg}, \mathrm{Fe}^{2+}=2 \mathrm{Al}\right)$

The characteristics of large biotite flakes (oldest generation) are: Si per formula unit $(\mathrm{pfu})=2.63$ in Cors15G and 2.65 in Cors17, $\mathrm{X}_{\mathrm{Mg}}=\mathrm{Mg} /(\mathrm{Mg}+\mathrm{Fe}+\mathrm{Mn})=0.38$ in Cors15G and 0.41 in Cors17, and $\mathrm{Ti}$ as $\mathrm{TiO}_{2}$ in $\mathrm{wt} \%=2.7$ in Cors $15 \mathrm{G}$ and 2.4 in Cors 17 . The small flakes of the second mica generation in Cors 17 show a lower $\mathrm{TiO}_{2}$ content of about $1.1 \mathrm{wt} \%$. $\mathrm{X}_{\mathrm{Mg}}$ $(0.42)$ is only slightly above that of the large flakes.

Plagioclase in the studied micaschists is oligoclase with anorthite contents of 21-22 $\mathrm{mol} \%$ in Cors $15 \mathrm{G}$ and $16 \mathrm{~mol} \%$ in Cors $17 . \mathrm{K}$-feldspar contents are $2.5 \mathrm{~mol} \%$ in Cors $15 \mathrm{G}$ and around $1.5 \mathrm{~mol} \%$ in Cors 17 . The composition of K-feldspar found in Cors 17 is close to that of the ideal end-member (Table 2).

\section{PRESSURE-TEMPERATURE EVOLUTION}




\section{Applied method}

254 We calculated $P-T$ pseudosections with the PERPLE_X computer programme package (see 255 Connolly, 2005; version from August 2011 downloaded from the internet site 256 http://www.perplex.ethz.ch/) to derive the $P-T$ evolution of the micaschists. The $P-T$ range of 1-16 kbar and 400-700 ${ }^{\circ} \mathrm{C}$, the system Si-Ti-Al-Mg-Mn-Fe-Ca-Na-K-H-O, and the thermodynamic data set of Holland \& Powell (1998, updated 2002) for $\mathrm{H}_{2} \mathrm{O}$ and minerals, which were pure phases, such as rutile and clinozoisite, and various solid-solutions described by the following models (see the PERPLE_X file solution_model dat), were considered: (1) TiBio(HP) for biotite being identical to the previous model Bio(HP) of Powell \& Holland (1999) as the tbi component was excluded (see below), (2) Chl(HP) for chlorite based on the formulation by Holland et al. (1998), (3) Ctd(HP) for chloritoid ("from THERMOCALC", written comm. by J.A.D. Connolly), (4) feldspar for ternary feldspar according to Fuhrman \& Lindsley (1988), (5) Gt(HP) for garnet (Holland \& Powell, 1998) with maximal 60 mol\% spessartine component, (6) Opx(HP) for orthopyroxene (Powell \& Holland, 1999), (7) Mica(M) for paragonite (Massonne, 2010) with maximal $50 \mathrm{~mol} \%$ muscovite component, (8) Pheng(HP) for potassic white mica (see Powell \& Holland, 1999, as well as comments in file newest_format_solut.dat) with maximal $50 \mathrm{~mol} \%$ paragonite component, and (9) St(HP) for staurolite ("from THERMOCALC", written comm. by J.A.D. Connolly). In fact, we used older solid-solution models for clinopyroxene and amphibole, Omph(HP) based on the thermodynamic data given by Holland \& Powell (1996), augmented by those of the end members aegirine and $\mathrm{CaAl}_{2} \mathrm{SiO}_{6}$ (see Zeh et al., 2005), and GITrTsPg (glaucophane-

274 tremolite-tschermakite-pargasite + corresponding $\mathrm{Fe}^{2+}$-bearing components, Powell \& Holland, 1999), but these phases turned out to be not of relevance for the here derived P-T conditions. For cordierite and ilmenite the ideal solid-solution models hCrd and IlGkPy (max. $30 \mathrm{~mol} \%$ geikilite component), respectively, were used, which are based on the thermodynamic data for corresponding end-members given by Holland \& Powell (1998). The 
amphibole end-members acti, cumm, and grun, the abbreviated end-member phases ann1, mic (microcline), and ab (low $\mathrm{T}$ albite), and the $\mathrm{O}_{2}$ buffers $\mathrm{qfm}$ and $\mathrm{mthm}$ in the applied data file were not considered. Both Ti end-members tip and tbi in white and dark micas, respectively, were excluded because of their untrustworthiness (see, e.g., discussion in Massonne, 2012).

The bulk-rock compositions of the micaschists (Table 3), determined by XRF, were modified for the PERPLE_X calculations: (1) The $\mathrm{CaO}$ content was reduced because some $\mathrm{Ca}$ is bound to apatite, $\mathrm{Ca}_{5}\left(\mathrm{PO}_{4}\right)_{3}(\mathrm{OH}, \mathrm{F})$. Since several larger grains (see below) of monazite, $(\mathrm{Ce}, \mathrm{La}) \mathrm{PO}_{4}$, were found besides apatite grains in each thin section of the micaschists, we considered that a $\mathrm{CaO}$ content equivalent to two third of the analysed content of $\mathrm{P}_{2} \mathrm{O}_{5}$ in the bulk-rock was bound to apatite and correspondingly subtracted from the bulk-rock for the PERPLE_X calculations. In order to check the influence of this modification on the $P-T$ results for our Ca-poor bulk-rock compositions, we also achieved a calculation for CORS17 without this modification. (2) The oxygen content, which is related to the amount of trivalent iron in the rock, can have a significant influence on the $P-T$ results of medium to high temperature metapelites (Massonne, 2014). However, in the micaschists $\mathrm{Fe}^{3+}$ only occurs in very minor amounts in silicates (see garnet compositions in Table 1). Therefore, we estimated that less than $5 \%$ of the iron was trivalent during metamorphism. Consequently, the PERPLE_X calculations were undertaken either without $\mathrm{O}_{2}$ or a small $\mathrm{O}_{2}$ content equivalent to $5 \%$ of the iron being trivalent to check the influence of such small amounts of $\mathrm{Fe}^{3+}$ on our $P-T$ calculations. (3) A water content of $5 \mathrm{wt} \%$ was considered to permit the formation of a free hydrous fluid already at the lowest temperatures of our calculations. In one case, only $1.95 \mathrm{wt} \% \mathrm{H}_{2} \mathrm{O}$ was added to the dry bulk-rock composition to check the effect of waterundersaturated conditions at retrograde metamorphic conditions (for more details, see below). (4) For all PERPLE_X calculations, the sums of the oxide contents were normalized to 100 wt $\%$ (Table 3). For a late metamorphic stage, effective bulk-rock compositions are often considered, for instance, by subtracting garnet cores from the bulk-rock (e.g., Groppo \& 
Rolfo, 2008) although this has little effect even at significantly higher garnet contents than 2 vol.\% as in our rocks (e.g., Massonne, 2014, 2016a; Waizenhöfer \& Massonne, 2017). As the garnet grains are usually partially decomposed (Fig. 4), the garnet cores were clearly involved in retrograde reactions (already at high temperatures - see below) so that we considered the entire bulk-rock composition as being (nearly) effective during the entire metamorphism.

The obtained $P-T$ pseudosections were contoured by isopleths for molar fractions of garnet components, Si contents in potassic white mica and modal contents of garnet. Such isopleths were used to obtain metamorphic $P-T$ data.

\section{Calculation results and $P-T$ path}

314 The obtained $P$-T pseudosections (Fig. 8) for the five modified bulk-rock compositions with 5 $315 \mathrm{wt} \% \mathrm{H}_{2} \mathrm{O}$ (Table 3) resemble each other and those calculated (e.g., Massonne \& Toulkeridis, 2012; Massonne, 2016a; Waizenhöfer \& Massonne, 2017) for metamorphosed relatively

317 immature clastic sediments (bulk-rock compositions according to XRF analyses: $\mathrm{SiO}_{2}=58$ -

$31872 \mathrm{wt} \%, \mathrm{CaO}<1 \mathrm{wt} \%, \mathrm{~K}_{2} \mathrm{O}>3 \mathrm{wt} \%, \mathrm{Na}_{2} \mathrm{O}>0.8 \mathrm{wt} \%, \mathrm{Al}_{2} \mathrm{O}_{3}=15-21 \mathrm{wt} \%$, considerable $\mathrm{Fe}$ and $\mathrm{Mg}$ contents) at medium metamorphic grade $\left(450-650{ }^{\circ} \mathrm{C}, 2-16 \mathrm{kbar}\right)$. Typical features in such pseudosections for the given $P-T$ range are (1) the omnipresence of potassic white-mica (except at the lowest pressures and highest temperatures) and quartz, (2) the limitation of cordierite to pressures below $3.5 \mathrm{kbar}$, resulting only occasionally in an overlap of the P-T for Ca-richer metapelites by Jeřábek et al., 2008) at $650{ }^{\circ} \mathrm{C}$ (for Cors17: c. $8.5 \mathrm{kbar}$ ), (4) the occurrence of a small P-T field for staurolite (typically as shown in Fig. 9), and (5) a maximum pressure for ilmenite between 8.5 and 14 kbar (Cors17, see also Waizenhöfer \& Massonne, 2017) at a temperature $\geq 550{ }^{\circ} \mathrm{C}$. In addition, the occurrence of biotite and 
330 plagioclase can be limited to pressures of $10 \mathrm{kbar}$ at temperatures around $600{ }^{\circ} \mathrm{C}$. However in

331 case of micaschists Cors15G and Cors17, these upper pressure limits are clearly above 10

332 kbar. At temperatures above $450^{\circ} \mathrm{C}$, the mineral phases lawsonite, chloritoid and ( $\mathrm{Na}$ rich)

333 amphibole typically appear at HP conditions only (see Fig. 8a).

334 The variation of the composition of garnet and potassic white-mica in the

335 aforementioned medium-grade metamorphic rocks is likewise. The pyrope content in garnet

336 increases with rising temperature or, at pressures below approximately $10 \mathrm{kbar}$, rising

337 pressure at temperatures above $600^{\circ} \mathrm{C}$ (Fig. 8 b). At these temperatures, the grossular content

338 increases with pressure (up to 13-14 kbar). However, at HP conditions this increase results

339 rather from falling temperatures (Fig. 8b). The Si contents in potassic white-mica increase

340 with rising pressure (Fig. 8c), but this increase is moderate for low Si contents (6.0-6.1 pdfu)

341 compared to higher $\mathrm{Si}$ contents above c. $550^{\circ} \mathrm{C}$. For this reason, barometry with $\mathrm{Si}$ in potassic

342 white-mica is fairly insensitive at corresponding $P-T$ conditions for the above considered

343 metasediments. Thus, the derivation of these conditions in the following is based mainly on

344 the compositional and modal characteristics of garnet.

345 The consideration of some $\mathrm{Fe}^{3+}$ (5\% of the total iron) in the bulk rock composition

346 (Table 3) has a minor effect (shift by a few degrees only) on the $P$ - $T$ position of the kind of

347 isopleths, which are exemplarily shown in Figure 8, for the $P-T$ range (see below: $T>500^{\circ} \mathrm{C}$,

$348 P<10$ kbar) relevant for our micaschists (Cors15G and Cors17). The difference between the

$349 P-T$ limits of specific mineral phases in calculations without and with some $\mathrm{Fe}^{3+}$ can also be

350 very small (see the staurolite fields in Fig. 9b). This concerns the limit for garnet below 7 kbar

351 as well. However, at higher pressures $\left(T<520^{\circ} \mathrm{C}\right)$ a larger $P-T$ difference of the garnet limit is

352 discernable in Figure 9b. A considerable shift of the garnet isopleths for XCa toward lower

353 pressures (or higher $T$ ) is notable when the Ca correction for apatite is not applied (Fig. 9b).

354 This correction might be particularly critical for the thermodynamic modeling using garnet in 355 apatite-bearing rocks with low $\mathrm{CaO}$ content in the bulk rock. For this reason, Cors16 (Table 
3) was not modelled. Other kinds of isopleths considered here (XMg, XMn, vol\% of garnet,

Si in muscovite) are hardly affected. The $P-T$ field of garnet is somewhat extended at higher

$358 \mathrm{CaO}$ contents in the bulk-rock (Fig. 9b).

The compositional trend of garnet in Cors17 (Figs. 4 and 5) results in the $P-T$

conditions, marked by the grey ellipses in Figure $9 \mathrm{~b}$, when some $\mathrm{Fe}^{3+}$ in the bulk rock is

considered and the Ca correction for apatite is ignored. The peak $P-T$ conditions derived from

the garnet core composition $\mathrm{Alm}_{0.735} \mathrm{Gro}_{0.04} \mathrm{Pyr}_{0.125} \mathrm{Spe}_{0.10}$ are close to $7 \mathrm{kbar}$ and $600^{\circ} \mathrm{C}$. The inner garnet mantle composition $\mathrm{Alm}_{0.71} \mathrm{Gro}_{0.045} \mathrm{Pyr}_{0.115} \mathrm{Spe}_{0.13}$ points to a slight temperature decrease at constant pressure. At this stage, the calculated garnet volume is 2 vol.\% as observed (see above). The calculated contents of anorthite in plagioclase and $\mathrm{Si}$ in biotite are $15.5 \mathrm{~mol} \%$ and $2.685 \mathrm{pfu}$, respectively, which are close to the analysed values (Table 2). The compositions of large muscovite flakes (oldest generation) reach $\mathrm{Si}$ contents close to 6.20 pdfu (Fig. 7), compatible with the peak pressure conditions, but the majority is lower in $\mathrm{Si}$ (down to $6.05 \mathrm{pdfu}$ ) and, thus, should have formed at lower pressures and relatively high temperatures (e.g., $3.5 \mathrm{kbar}$ and $580^{\circ} \mathrm{C}$ ). The same should apply for sillimanite (relics) because the derived peak $P-T$ conditions are already outside the $P-T$ field of sillimanite (Fig. 9b). The subsequent compositional evolution towards the garnet rim $\left(\mathrm{Alm}_{0.725} \mathrm{Gro}_{0.025} \mathrm{Pyr}_{0.10} \mathrm{Spe}_{0.15}\right)$ points to decreasing pressure and temperature to $4.5 \mathrm{kbar}$ and $565-570{ }^{\circ} \mathrm{C}$. The derivation of the $P-T$ conditions using the calculation result for the bulk-rock composition of Cors 17 without $\mathrm{Fe}^{3+}$ and Ca correction (red ellipses in Fig. 9b) yields slightly higher peak pressures (less than 0.2 kbar) compared to the result with $\mathrm{Fe}^{3+}$ in the bulk-rock. Similar $P-T$ conditions were determined from the study of micaschist Cors15G. However, the P-T trajectory is a prograde one using the compositional trend of the extended garnet core (although strongly corroded) in this rock (Fig. 5). The XCa and XMg isopleths for the outer core composition $\left(\mathrm{Alm}_{0.73} \mathrm{Gro}_{0.04} \mathrm{Pyr}_{0.16} \mathrm{Spe}_{0.07}\right)$ and that for a garnet modal content of $2 \mathrm{vol} \%$ intersect at about $7 \mathrm{kbar}$ and $630^{\circ} \mathrm{C}$ (Fig. 9a) using the bulk-rock composition with 
382 no $\mathrm{Fe}^{3+}$ and $\mathrm{Ca}$ correction for apatite. Applying additionally to $\mathrm{XCa}$ and $\mathrm{XMg}$ isopleths those 383 for $\mathrm{XMn}$, the deducible prograde path starts, based on the inner core composition $384\left(\mathrm{Alm}_{0.70} \mathrm{Gro}_{0.04} \mathrm{Pyr}_{0.145} \mathrm{Spe}_{0.115}\right)$, at approximately $5.5 \mathrm{kbar}$ and $615^{\circ} \mathrm{C}$, when we take into 385 account that the $\mathrm{XCa}=0.04$ isopleth, as shown in Figure 9a, would shift to lower pressures if 386 this Ca correction is neglected. These P-T conditions as well as those at still lower pressures 387 (e.g. $3.5 \mathrm{kbar}$ and $580^{\circ} \mathrm{C}$ ) agree with the formation of sillimanite in Cors $15 \mathrm{G}$ (Fig. 3e) and the 388 dominance of muscovite with Si contents around 6.08 pdfu (Fig. 7). Again the contents of 389 anorthite in plagioclase and $\mathrm{Si}$ in biotite $(18 \mathrm{~mol} \%$ and $2.625 \mathrm{pfu})$, calculated for the peak $P-T$ 390 conditions, are compatible with analysed values (Table 2). However, the calculated Si content in biotite at $3.5 \mathrm{kbar}$ and $580^{\circ} \mathrm{C}$ is only $2.51 \mathrm{pfu}$. Although, the garnet mantle compositions with $\mathrm{Mg}$ contents lower than that of the outer core (Fig. 5) point already to slightly reduced temperatures, the garnet rim composition $\left(\mathrm{Alm}_{0.715} \mathrm{Gro}_{0.045} \mathrm{Pyr}_{0.06} \mathrm{Spe}_{0.18}\right)$ was thought to be helpful in determining the $P-T$ conditions of a late metamorphic stage. Unfortunately, the corresponding $\mathrm{XCa}$ and $\mathrm{XMg}$ isopleths intersect somewhat outside the $P-T$ field of garnet (Fig. 9a) at approximately $530{ }^{\circ} \mathrm{C}$ and 3.5 kbar. We followed the idea that a deficit of $\mathrm{H}_{2} \mathrm{O}$, typical for retrograde conditions, could bring this intersection into a more extended garnet field. Therefore, we calculated several pseudosections for Cors $15 \mathrm{G}$ with various $\mathrm{H}_{2} \mathrm{O}$ deficits. Even a slight deficit as given in Table 3 (see also the $\mathrm{V}$ out curve in Fig. 9a) leads, in fact, to a significant extension of the garnet field to lower temperatures, but the relevant $\mathrm{XMg}=0.06$ together with this white mica the minimum temperature could be as low as $400{ }^{\circ} \mathrm{C}$ (see breakdown curve of biotite in Massonne \& Willner, 2008) or still less depending on pressure (Massonne, 2010; this work). As virtually no chlorite occurs in Cors15G higher temperatures 
than $400^{\circ} \mathrm{C}$ seem to us to be likely. Nevertheless, we estimated c. $400^{\circ} \mathrm{C}$ and $3 \mathrm{kbar}$ as possible retrograde conditions.

The thermodynamic modeling for micaschists Cors15G and Cors17 results in anticlockwise $P$-T paths (Fig. 9), which have a hair-pin shape close to the peak $P-T$ conditions of 7 kbar and 630 (Cors15G) or $600{ }^{\circ} \mathrm{C}($ Cors 17$)$.

\section{DATING RESULTS OF MONAZITE}

Monazite appears as rather large grains in both micaschists, Cors15G and Cors17. Several grains with sizes above $50 \mu \mathrm{m}$ were found in each studied thin-section. The maximum size was about $200 \mu \mathrm{m}$ (see Fig. 10). In back-scattered electron (BSE) images, obtained with the EMP, complex zonations are discernable. From a few monazite grains, elemental maps (Ca, $\mathrm{Y}, \mathrm{Ce}, \mathrm{Gd}, \mathrm{Th})$ were produced. The most obvious zonations can be recognized in Y maps (Fig. 10). Spot analyses (Cors15G: 21 grains, 38 analyses; Cors 17: 17 grains, 35 analyses) lead to a chemical characterization of various monazite domains and U-Th-Pb ages (Table 4). The results are presented in Figure 10 in terms of $\mathrm{Y}_{2} \mathrm{O}_{3}$ content in $\mathrm{wt} \%$ and the $\mathrm{La} / \mathrm{Gd}$ and $\mathrm{Th} / \mathrm{U}$ ratios plotted versus the age.

The obtained 73 ages scatter between 328 and 384 Ma (Fig. 10). Especially the Y contents in monazite vary significantly and, thus, allow a chemical discrimination of monazite domains, which are already discernable in $\mathrm{Y}$ maps of monazite. In Figure 10c, three such domains of low, medium, and high Y contents can be recognized. Accordingly, we arbitrarily defined two Y limits (see Fig. 10e) to discriminate between monazite populations. Using the Isoplot programme, the ages of these populations are: $362.2 \pm 4.1(2 \sigma, 95 \%$ confidence level $)$ Ma (mean square of weighted deviates $=$ MSWD: 2.7) for the high-Y population, $350.8 \pm 4.2$ Ma (MSWD: 1.7) for the medium-Y population, and 340.5 \pm 4.4 Ma (MSWD: 2.7) for the low-Y population. As the three oldest ages of the latter population are characterized by 
unusual high $\mathrm{Th} / \mathrm{U}$ ratios, we recalculated the age for this population without these three data; an age of $337.1 \pm 2.8 \mathrm{Ma}$ (MSWD: 1.0 ) resulted. The three populations are characterized by mean $\mathrm{La} / \mathrm{Gd}$ ratios of 9.9 (high $\mathrm{Y}$ ), 12.2 (medium $\mathrm{Y}$ ), and 20.2 (low $\mathrm{Y}$ ). The $\mathrm{Th} / \mathrm{U}$ ratios of the analyzed monazite scatter around 6 (Fig. 10e).

\section{DISCUSSION}

\section{Metamorphic evolution}

According to the above outlined derivation of metamorphic conditions for the studied micaschists Cors $15 \mathrm{G}$ and Cors17, representing a metasedimentary sequence of two basement areas near Porto Vecchio (Figs. 1 and 2), the peak $P$ - $T$ conditions could be well constrained. Peak pressures are close to $7 \mathrm{kbar}$. Peak temperatures were $630^{\circ} \mathrm{C}$ regarding the area at Punta di a Chiappa, a few km east of Porto Vecchio, whereas $600{ }^{\circ} \mathrm{C}$ resulted for the area at Punta di Fautea, $15 \mathrm{~km}$ north-east of Porta Vecchio. In fact, prograde and retrograde paths to and from peak conditions could be less well constrained, but these branches of the $P$ - $T$ paths seem to be at least similar for both study areas (Fig. 9). On the basis of these paths and our textural observations (section MINERAL TEXTURES AND COMPOSITIONS), a consistent picture for the evolution of the studied metamorphic rocks can be reconstructed: At about $3 \mathrm{kbar}$ (c. $12 \mathrm{~km}$ Earth depth) and $550-600{ }^{\circ} \mathrm{C}$, relatively coarse-grained (grain sizes around $1 \mathrm{~mm}$ ) micaschists, consisting mainly of quartz, plagioclase, muscovite (Si pdfu: 6.06-6.10), biotite, and sillimanite, had formed in a regional environment characterized by high geothermal gradients of $45-50{ }^{\circ} \mathrm{C} / \mathrm{km}$. During the subsequent burial to depths of c. $25 \mathrm{~km}(P$ of $7 \mathrm{kbar})$ garnet started to grow and occasionally formed porphyroblasts (Figs. 2c, 3b). Probably before reaching peak $P-T$ conditions a major deformation event occurred leading, for instance, to growth of relatively small micas at the expense of stressed palaeograins of both biotite and muscovite. Contents of $\mathrm{Si}$ in the newly formed muscovite are correspondingly higher (e.g., 
6.16 pdfu in Cors17, see Fig. 7) than in the palaeograins. Replacement of sillimanite by finegrained muscovite started probably at this stage, but continued during exhumation (retrograde path) under formation of very-fine grained micas (Fig. 3e). At the very early retrogression (soon after passing the $P-T$ peak) garnet was corroded and replaced by retrograde garnet (Cors17), i.e. garnet richer in Mn than the early prograde garnet, or by micas (Cors15G). The latter replacement feature was probably caused by fluid infiltration resulting in a significant corrosion of garnet to form pinite-like mica aggregates (Fig. 3b). Even in such aggregates a slight re-growth of relatively Mn-rich garnet (Fig. 5a) happened. This event was assigned to $P-T$ conditions of $530^{\circ} \mathrm{C}$ and $3.5 \mathrm{kbar}$ (see above).

The anti-clockwise path with hair-pin shape, which is consistent with the textural and chemical evolution of the micaschist minerals, is in clear contrast (see Fig. 9c) to the clockwise $P$-T path of Giacomini et al. (2008) suggesting clearly higher pressures (at least 9 kbar) at the beginning of the recorded metamorphic evolution, higher peak temperatures $\left(>650{ }^{\circ} \mathrm{C}\right)$, and lower pressures $(1-2 \mathrm{kbar})$ at a late metamorphic stage $\left(T>500{ }^{\circ} \mathrm{C}\right)$ compared to our path. To appraise this clockwise path, it must be noted that Giacomini et al. (2008) considered broadly the change of mineral assemblages and, to a limited extend, mineral compositions, such as the Si content in potassic white mica $(<6.2 \mathrm{pdfu}$ as hint at $P<5 \mathrm{kbar}-$ compare with Fig. 9a), for their $P-T$ estimations. Only one calculation with THERMOCALC was presented by these authors for the assemblage biotite-muscovite-garnet-sillimaniteplagioclase resulting in $P-T$ conditions of $5.2 \mathrm{kbar}$ at $660^{\circ} \mathrm{C}$, which might be within errors even compatible with our $P$ - $T$ estimates. However, it is not clear which mineral compositions were used by Giacomini et al. (2008) to obtain this $P-T$ datum. Therefore, we suspect that the mineral compositions applied by these authors were not in equilibrium. According to our $P-T$ paths, garnet and sillimanite were in equilibrium only in a narrow $P-T$ range (for Cors $15 \mathrm{G}$ around $5 \mathrm{kbar}$ and $610{ }^{\circ} \mathrm{C}$, see Fig. 9a). According to Giacomini et al. (2008), the early retrograde path proceeded at very low pressures (Fig. 9c). However, this view, which is in 
contrast to our findings, might have resulted from the error that the "pinite" aggregates (see above) represent retrogressed cordierite. In addition, Giacomini et al. (2008) had focussed not only on the Porto Vecchio - Fautea metasedimentary rock sequence, as in this study, but considered various rock types in the Porto Vecchio area including igneous rocks, to define a $P$-T-time path. According to our field study, we assume a tectonic boundary north of Punta di Fautea as the rocks there show significant migmatization, so that the higher temperatures, estimated by Giacomini et al. (2008) for the basement of Porto Vecchio could, indeed, be valid for this migmatized area. The granulites north of this area (granulites of FauteaSolenzara) had experienced HP conditions at temperatures above $800^{\circ} \mathrm{C}$ before they joined the metamorphic evolution of the Porto Vecchio basement, i.e. they should have experienced the same P-T conditions as the rocks from the Porto Vecchio area (Giacomini et al., 2008). The boundary of the Porto Vecchio-Fautea metasedimentary rock sequence to the south could be the PVSZ (Fig. 1b).

\section{Age constraints}

Typically, single monazite grains can contain different compositional domains providing information on the geological history of the host rock (Williams et al., 2007). According to the different chemical compositions of monazite in the studied micaschists, three populations were distinguished (high, medium, and low Y) showing different ages $(362,351,341$ or 337 Ma depending on the rejection of possible outliers). It is not fully clear, if the medium-Y population results from the analysis of a mixture of high- and low-Y domains or represents a true discrete population, although the $\mathrm{Y}$ map of Figure 10c suggests three different $\mathrm{Y}$ domains. Because of this ambiguity, we discuss in the following the meaning of the high- and low-Y domains only. Monazite containing more than $2 \mathrm{wt} \% \mathrm{Y}_{2} \mathrm{O}_{3}$ in metamorphic rocks usually formed before garnet, which competes with monazite for the trace contents of $\mathrm{Y}$ in a rock, or by strong retrogression of this phase (see, e.g., Massonne, 2014, 2016a). As our highY population is the oldest $(\sim 362 \mathrm{Ma})$ of the three ones in the micaschists, we suggest that it 
510 had formed before garnet started to grow. This is the case at pressures lower than $3 \mathrm{kbar}$ (Fig.

$5119 \mathrm{~b})$ along the early prograde path. The preservation of monazite, formed already along such a

512 path, might be rare but examples of preserved prograde monazite, which was even not 513 shielded, for instance, as inclusion in garnet, exist in the literature (e.g., Langone et al., 2011).

514 Although zircon and monazite can give different ages in single rocks (Zeh et al., 2003), a 515 similar age of $361 \pm 3$ Ma was obtained by Giacomini et al. (2008) from dating zircon in the 516 Fautea-Solenzara granulites (see above). These authors assigned this Late Devonian age to the 517 HP event of the granulites.

518 Some analyses of grains of the low-Y monazite population yielded Y contents even 519 below the detection limit. We suggest that this population grew after garnet had grown and 520 introduced the available Y. Another constraint for the relation of the age of the low-Y 521 monazite population $(\sim 340 \mathrm{Ma})$ to the metamorphic evolution of the micaschists is the fact 522 that the high-Y monazite was significantly corroded and replaced by low-Y monazite. This 523 process can be deduced, for instance, from the elemental maps of the monazite of Figure 10.

524 The high-Y domains in this grain survived only as relics. Even inner parts of this grain were 525 replaced by the significantly younger low-Y domain. Thus, we assume that a deformational 526 event or, more likely, the infiltration of hydrous fluids (see, e.g., Williams et al., 2011; Lo Pò 527 et al., 2016) have caused the clear corrosion of high-Y monazite and its replacement by 528 younger monazite. Such an event (deformation as reported above; fluid infiltration also resulted in partial replacement of sillimanite by micas) occurred close to peak $P-T$ conditions 530 after garnet had broadly grown. Even at very early retrograde conditions, an infiltration of 531 hydrous fluids was noted leading to the corrosion of garnet. This process could have, in fact, 532 released $\mathrm{Y}$, but $\mathrm{Y}$ contents corresponding to up to $0.65 \mathrm{wt} \% \mathrm{Y}_{2} \mathrm{O}_{3}$ were found in monazite of 533 the low-Y population. Based on the above discussion, we think that the peak $P-T$ conditions 534 were reached at about $340 \mathrm{Ma}$ or a bit earlier. 
536 concordia age of the youngest zircon population in a two-mica gneiss from the Punta di a

537 Chiappa area. These authors related this age rather to the peak pressure of the

538 metasedimentary rocks, but not to the peak temperature event, which was assumed to be

539 somewhat younger (see Fig. 9c). The retrogression at still high temperatures was proposed by

540 Giacomini et al. (2008) to have taken place mainly between 310 and $320 \mathrm{Ma}$ (Fig. 9c). As

541 such young monazite was not found in our micaschists, we doubt that these relatively young

542 ages, obtained from igneous rocks (Giacomini et al., 2008), are relevant for the early

543 retrogression of the metamorphic rocks.

\section{Geodynamic scenario}

545 Giacomini et al. (2008) presented a geodynamic scenario for the evolution of the Corsica-

546 Sardinia section of the Variscan orogen. This scenario is related to the collision of two

547 continental plates, which started at about $360 \mathrm{Ma}$ or somewhat earlier and led to continental

548 subduction until the adhered oceanic crust was separated (slab break-off event). Giacomini et

549 al. (2008) suggested these processes on the basis of the metamorphic evolution of the Fautea-

550 Solenzara granulites deduced by these authors. The subsequent evolution, characterized by

551 back-thrusting of slices from regions of thickened continental crust in major strike-slip shear

552 zones in the time interval $350-315 \mathrm{Ma}$, is based on the $P$-T-time evolution derived from

553 gneisses and migmatites of the Porto Vecchio area (Giacomini et al., 2008). Our new findings

554 on the studied micaschists from the Porto Vecchio-Fautea metasedimentary sequence, allow

555 us to propose a modified collisional model.

556 In Figure 11, the evolution, exhibited in a two-dimensional scenario, starts with the

557 final subduction of oceanic crust in Late Devonian times. The dehydration of the subducted

558 crust has led to a magmatic arc which formed at the southern margin of Laurussia following,

559 for instance, Rossi et al. (2009). The studied micaschists were situated in medium crustal

560 depths $(\sim 12 \mathrm{~km}$, see above) close to this arc at that time because this seems to be the most

561 likely environment responsible for the high geothermal gradients $\left(45-50{ }^{\circ} \mathrm{C} / \mathrm{km}\right)$ which were 
562 deduced for the early evolution of the micaschists. The subsequent burial of these rocks to 563 depths of $25 \mathrm{~km}$ was induced by the initial collision of Gondwana and Laurussia at the 564 beginning of the Carboniferous (after formation of our high-Y monazite population at 362 $565 \mathrm{Ma}$ ). At the same time, the magmatic arc became extinct because of the break-off of the 566 oceanic plate which was adhered to Gondwana. In fact, this slab break-off process is assumed, 567 by various authors to have taken place later (e.g., von Raumer et al., 2014: 340-335 Ma; 568 Casini et al., 2015: 345-340 Ma with preference for $345 \mathrm{Ma}$ ), we think that no good evidence 569 exists for the Variscan timing of this process yet.

570 In contrast to the micaschists, metamorphic rocks of the wider vicinity (those of NE 571 Sardinia - see section GEOLOGICAL SETTING, General aspects) experienced HP 572 conditions in the early Carboniferous as they were part of the downgoing continental plate 573 and, thus, more deeply settled as the micaschists from the upper continental plate. However, 574 both micaschists and HP rocks might have been more or less contemporaneously involved in 575 back thrusting in an exhumation channel (for definition see, e.g., Massonne, 2016b) which 576 comprises deeply buried sediments (e.g. HP micaschists reported by Cruciani et al., 2013) and 577 the adjacent uppermost portion of the downgoing plate and lowermost portion of the upper plate (see Fig. 11). This back-thrusting event, which might be typical for continent-continent collision settings (compare with the Himalayas: e.g. Catlos et al., 2001; Iaccarino et al., 2015; Carosi et al., 2017), could have started after significant thrusting of the Gondwana margin under Laurussia (around $345 \mathrm{Ma}$ ). This event resulted in exhumation of the micaschists accompanied by cooling and penetration of hydrous fluids (at about $340 \mathrm{Ma}$ according to the 583 low-Y monazite population) because the sediments in the exhumation channel and the underlying upper portion of the downgoing plate, which were still relatively cold, were heated and, thus, dehydrated. These rocks experienced $P-T$ conditions along a clockwise loop (see, e.g., Cruciani et al., 2013) whereas the studied micaschists were metamorphosed along an anti-clockwise $P-T$ path. Due to the back-thrusting event, rock slices from different crustal 
588 levels of both upper and lower continental plates were brought relatively close together 589 probably still in Viséan times.

590 Shearing probably along strike-slip faults (see Giacomini et al., 2008), which cannot 591 be demonstrated in our two-dimensional model (Fig. 11), affected the Porto Vecchio 592 basement including the studied micaschists (see above). According to our geodynamic model 593 this tectonic event has already taken place in early Carboniferous times during the early 594 exhumation of the studied micaschists. Casini et al. (2015) assumed that such an event in the 595 Corsica-Sardinia block in the time interval 325-300 Ma has caused the production of large 596 volumes of granitic melts forming extended batholiths in the Inner Zone of this block. This 597 time interval is consistent with a major phase of transpression coeval with the development of 598 lithospheric-scale shear zones between about 320 and 305 Ma (Di Vincenzo et al., 2004; 599 Carosi et al., 2012). The contrasting time intervals are probably related to an apparent 600 difference because compressional shearing seems to have occurred over a long period of time 601 eventually during the entire Variscan orogeny.

602

603 CONCLUSIONS

604 The study of a single rock sequence, characterized by similar metamorphic rock types (here 605 metasediments), is worthwhile because it results in deeper insights into the evolution of crust 606 during an orogenic event compared to the overall consideration of a crustal section which 607 could not be as coherent as assumed. Occasionally, such a study reveals an anti-clockwise P-T 608 loop (e.g., Pitra \& Guiraud, 1996; Waizenhöfer \& Massonne, 2017). This is the case for the 609 here investigated micaschist-paragneiss sequence in the Corsican Porto Vecchio basement, 610 which, in contrast to the previous study by Giacomini et al. (2008), experienced peak $P-T$ 611 conditions of $7 \mathrm{kbar}$ at $600-630{ }^{\circ} \mathrm{C}$. The prograde path of these rocks passed through 612 relatively high temperatures (close to $600^{\circ} \mathrm{C}$ ) at low pressures (around 4 kbar). The $P-T$ 
613 evolution of the micaschist-paragneiss sequence, which might be bounded by strike-slip faults 614 (in the south by the PVSZ), is explained by a geotectonic scenario related to the Variscan 615 orogenesis (Fig. 11). This sequence experienced the high temperature - low pressure 616 metamorphism close to a magmatic arc at c. $362 \mathrm{Ma}$ according to the here presented monazite 617 ages. The burial of this unit to depths of $25 \mathrm{~km}$ was initiated by continent-continent collision. 618 The subsequent exhumation is hypothesized to have been accomplished by back-thrusting of 619 continental slices in an exhumation channel.

620

621

622

623

624

625

626

627

628

\section{ACKNOWLEDGEMENTS}

The authors thank Thomas Theye (Stuttgart) for his support of the work with the EMP. Sampling was carried out during a short-term visit of H.-J.M. at Università degli Studi di Cagliari funded by the visiting professor programme. M.F. and G.C. benefited from funds granted by Università degli Studi di Cagliari.

\section{REFERENCES}

Bernhardt, H.-J., 2007. MINCALC-V5, a software tool for mineral analyses data processing. Acta Microscopica, 16, 1-2, (Suppl. 2), 43.

Brandelik, A., 2009. CALCMIN - an EXCEL ${ }^{\mathrm{TM}}$ Visual Basic application for calculating mineral structural formulae from electron microprobe analyses. Computers \& Geosciences, 35, 1540-1551.

Carmignani, L., Carosi, R., Di Pisa, A., Gattiglio, M., Musumeci, G., Oggiano, G. \& Pertusati, P. C., 1994. The Hercynian chain in Sardinia (Italy). Geodinamica Acta 7, $31-47$.

Carmignani, L., Oggiano, G., Barca, S., Conti, P., Eltrudis, A., Funedda, A., Pasci, S. \& 
Salvadori, I., 2001. Geologia della Sardegna (Note illustrative della Carta Geologica della Sardegna in scala 1:200000). Memorie descrittive della Carta Geologica d'Italia, Vol. LX, Servizio Geologico Nazionale. Istituto Poligrafico e Zecca dello Stato, Roma, 283 pp.

Carosi, R., Montomoli, C., Tiepolo, M. \& Frassi, C., 2012. Geochronological constraints on post-collisional shear zones in the Variscides of Sardinia (Italy). Terra Nova, 24, 4251.

Carosi, R., Montomoli, C., Iaccarino, S., Massonne, H.-J., Rubatto, D., Langone, A., Gemignani, L. \& Visonà, D., 2017. Middle to late Eocene exhumation of the Greater Himalayan Sequence in the Central Himalayas: Progressive accretion from the Indian plate. Geological Society of America Bulletin, 128, 1571-1592.

Carosi, R. \& Oggiano, G., 2002. Transpressional deformation in northwestern Sardinia (Italy): insights on the tectonic evolution of the Variscan Belt. Comptes Rendus Geoscience, 334, 287-294.

Carosi, R. \& Palmeri, R., 2002. Orogen-parallel tectonic transport in the Variscan belt of northeastern Sardinia (Italy): implications for the exhumation of medium-pressure metamorphic rocks. Geological Magazine, 139, 497-511.

Casini, L., Cuccuru, S., Puccini, A., Oggiano, G. \& Rossi, P., 2015. Evolution of the CorsicaSardinia Batholith and late-orogenic shearing of the Variscides. Tectonophysics, 646, 65-78.

Catlos, E.J., Harrison, T.M., Kohn, M.J., Grove, M., Ryerson, F.J., Manning, C.E. \& Upreti, B.N., 2001. Geochronologic and thermobarometric constraints on the evolution of the Main Central Thrust, central Nepal Himalaya. Journal of Geophysical Research, 106, 16177-16204.

Connolly, J.A.D., 2005. Computation of phase equilibria by linear programming: a tool for geodynamic modeling and its application to subduction zone decarbonation. Earth and 
Cortesogno, L., Gaggero, L., Oggiano, G. \& Paquette, J.-L., 2004. Different tectono-thermal evolutionary paths in eclogitic rocks from the axial zone of the Variscan chain in Sardinia (Italy) compared with the Ligurian Alps. Ofioliti, 29, 125-144.

Cruciani, G., Franceschelli, M., Elter, F. M., Puxeddu, M. \& Utzeri, D., 2008a. Petrogenesis of Al-silicate-bearing trondhjemitic migmatites from NE Sardinia, Italy: Lithos, 102, 554-574.

Cruciani, G., Franceschelli, M., Jung, S., Puxeddu, M. \& Utzeri, D., 2008b. Amphibolebearing migmatites from the Variscan Belt of NE Sardinia, Italy: Partial melting of mid-Ordovician igneous sources: Lithos, 105, 208-224.

Cruciani, G., Franceschelli, M. \& Groppo, C., 2011. P-T evolution of eclogite-facies metabasite from NE Sardinia, Italy: insights into the prograde evolution of Variscan eclogites. Lithos, 121, 135-150.

Cruciani, G., Franceschelli, M., Groppo, C. \& Spano, M.E., 2012. Metamorphic evolution of non-equilibrated granulitized eclogite from Punta de li Tulchi (Variscan Sardinia) determined through texturally controlled thermodynamic modelling. Journal of Metamorphic Geology, 30, 667-685.

Cruciani, G., Franceschelli, M., Massonne, H.-J., Carosi, R. \& Montomoli, C., 2013. Pressure-temperature and deformational evolution of high-pressure metapelites from Variscan NE Sardinia, Italy. Lithos, 175-176, 272-284.

Cruciani, G., Franceschelli, M., Groppo, C., Oggiano, G. \& Spano, M.E. 2015. Reequilibration history and P-T path of eclogites from Variscan Sardinia, Italy: a case study from the medium-grade metamorphic complex. International Journal of Earth Sciences, 104, 797-814.

Cruciani, G., Franceschelli, M., Massonne, H.-J., Musumeci, G. \& Spano, M. E., 2016. Thermomechanical evolution of the high-grade core in the nappe zone of Variscan 
Sardinia, Italy: the role of shear deformation and granite emplacement. Journal of metamorphic Geology, 34, 321-342.

692

693

694

695

696

697

698

699

700

701

702

703

704

705

706

707

708

709

710

711

712

713

714

715

Di Vincenzo, G., Carosi, R. \& Palmeri, R., 2004. The Relationship between tectonometamorphic evolution and argon isotope records in white mica: constraints from in situ ${ }^{40} \mathrm{Ar}-{ }^{39} \mathrm{Ar}$ laser analysis of the Variscan basement of Sardinia. Journal of Petrology, 45, 1013-1043.

Elter, F.M., Musumeci, G. \& Pertusati, P.C., 1990. Late Hercynian shear zones in Sardinia. Tectonophysics, 176, 387-404.

Elter, F.M., Faure, M., Ghezzo, C. \& Corsi, B., 1999. Late Hercynian shear zones in northeastern Sardinia (Italy): Géologie de la France, 2, 3-16.

Faure, M., Rossi, P., Gaché, J., Melleton, J., Frei, D., Li, X. \& Lin, W., 2014. Variscan orogeny in Corsica: new structural and geochronological insights, and its place in the Variscan geodynamic framework. International Journal of Earth Sciences, 103, 1533 1551.

Franceschelli, M., Puxeddu, M., Cruciani, G. \& Utzeri D., 2007. Metabasites with eclogite facies relics from Variscides in Sardinia, Italy: a review. International Journal of Earth Sciences, 96, 795-815.

Fuhrman, M.L. \& Lindsley, D.H., 1988. Ternary-feldspar modeling and thermometry. American Mineralogist, 73, 201-215.

Ghezzo, C. \& Orsini, J.-B., 1982. Lineamenti strutturali e composizionali del batolite ercinico Sardo-Corso in Sardegna. In: Carmignani, L., Cocozza, T., Ghezzo, C., Pertusati, P. C. \& Ricci C. A. (eds.) Guida alia geologia del Paleozoico sardo. Guide geologiche regionali. Memorie della Società Geologica Italiana, 165-181.

Giacomini, F., Bomparola, R.M. \& Ghezzo, C., 2005. Petrology and geochronology of metabasites with eclogite facies relics from NE Sardinia: constraints for the Palaeozoic evolution of Southern Europe. Lithos, 82, 221-248. 
716 Giacomini, F., Dallai, L., Carminati, E., Tiepolo, M. \& Ghezzo, C., 2008. Exhumation of a 717 Variscan orogenic complex: insights into the composite granulitic-amphibolitic 718 metamorphic basement of south-east Corsica (France). Journal of Metamorphic 719 Geology, 26, 403-436.

720

721

Groppo, C. \& Rolfo, F. 2008. Counterclockwise P-T evolution of the Aghil Range: Metamorphic record of an accretionary melange between Kunlun and Karakorum (SW Sinkiang, China). Lithos, 105, 365-378.

Holland, T. \& Powell, R., 1996. Thermodynamics of order-disorder in minerals: II. Symmetric formalism applied to solid solutions. American Mineralogist, 81, 1425 1437.

Holland, T.J.B. \& Powell, R., 1998. An internally consistent thermodynamic data set for phases of petrological interest. Journal of Metamorphic Geology, 16, 309-343.

Holland, T., Baker, J. \& Powell, R., 1998. Mixing properties and activity-composition relationships of chlorites in the system $\mathrm{MgO}-\mathrm{FeO}-\mathrm{Al}_{2} \mathrm{O}_{3}-\mathrm{SiO}_{2}-\mathrm{H}_{2} \mathrm{O}$. European Journal of Mineralogy, 10, 395-406.

Iaccarino, S., Montomoli, C., Carosi, R., Massonne, H.-J., Langone, A. \& Visonà, D., 2015. Pressure-temperature-time-deformation path of kyanite-bearing migmatitic paragneiss in the Kali Gandaki valley (Central Nepal): Investigation of Late Eocene-Early Oligocene melting processes. Lithos, 231, 103-121.

Iacopini, D., Carosi, R., Montomoli, C. \& Passchier, C. W., 2008. Strain analysis and vorticity of flow in the northern Sardinian Variscan belt: recognition of a partitioned oblique deformation event. Tectonophysics, 446, 77-96.

Jeřábek, P., Janák, M., Faryad, S.W., Finger, F. \& Konečný, P., 2008. Polymetamorphic evolution of pelitic schists and evidence for Permian low-pressure metamorphism in the Vepor Unit, West Carpathians. Journal of Metamorphic Geology, 26, 465-485.

Langone, A., Braga, R., Massonne, H.-J. \& Tiepolo, M., 2011. Preservation of old (prograde 
metamorphic) $\mathrm{U}-\mathrm{Th}-\mathrm{Pb}$ ages in unshielded monazite from the high-pressure paragneisses of the Variscan Ulten Zone (Italy). Lithos, 127, 68-85.

Liu, Y., Siebel, W., Theye, T. \& Massonne, H.-J., 2011. Isotopic and structural constraints on the late Miocene to Pliocene evolution of the Namche Barwa area, eastern Himalayan syntaxis, SE Tibet. Gondwana Research, 19, 894-909.

Lo Pò, D., Braga, R., Massonne, H.-J., Molli, G., Montanini, A. \& Theye, T., 2016. Fluidinduced breakdown of monazite in medium-grade metasedimentary rocks of the Pontremoli basement (Northern Apennines, Italy). Journal of Metamorphic Geology, 34, 63-84.

Ludwig, K. R., 1999. Isoplot/Ex, Version 2.06: A Geochronological Tool-kit for Microsoft Excel. 1a. Berkeley Geochronology Center, Special Publications, pp. 1-49.

Massonne, H.-J., 2010. Phase relations and dehydration behaviour of calcareous sediments at very-low to low grade metamorphic conditions. Periodico di Mineralogia, 79, 21-43.

Massonne, H.-J., 2012. Formation of amphibole and clinozoisite-epidote in eclogite owing to fluid infiltration during exhumation in a subduction channel. Journal of Petrology, 53, 1969-1998.

Massonne, H.-J., 2014. Wealth of P-T-t information in medium-high grade metapelites: Example from the Jubrique Unit of the Betic Cordillera, S Spain. Lithos, 208-209, $137-157$.

Massonne, H.-J., 2016a. Tertiary high-pressure metamorphism recorded in andalusite-bearing mica-schist, southern Pirin Mts., SW Bulgaria. European Journal of Mineralogy, in press. doi: 10.1127/ejm/2016/0028-2575.

Massonne, H.-J., 2016b. Hydration of the lithospheric mantle by the descending plate in a continent-continent collisional setting and its geodynamic consequences. Journal of Geodynamics, 96, 50-61.

Massonne, H.-J. \& Schreyer, W., 1986. High-pressure syntheses and X-ray properties of 
white micas in the system $\mathrm{K}_{2} \mathrm{O}-\mathrm{MgO}-\mathrm{Al}_{2} \mathrm{O}_{3}-\mathrm{SiO}_{2}-\mathrm{H}_{2} \mathrm{O}$. Neues Jahrbuch für Mineralogie Abhandlungen, 153, 177-215.

770

Massonne, H.-J. \& Toulkeridis, T., 2012. Widespread relics of high-pressure metamorphism confirm major terrane accretion in Ecuador: a new example from the Northern Andes. International Geology Review, 54, 67-80.

Massonne, H.-J. \& Willner, A.P., 2008. Dehydration behaviour of metapelites and mid-ocean ridge basalt at very-low to low grade metamorphic conditions. European Journal of Mineralogy, 20, 867-879.

Massonne, H.-J., Dristas, J.A. \& Martínez, J.C., 2012. Metamorphic evolution of the Río de la Plata craton in the Cinco Cerros area, Buenos Aires Province, Argentina. Journal of South American Earth Sciences, 38, 57-70.

Massonne, H.-J., Cruciani, G. \& Franceschelli, M., 2013. Geothermobarometry on anatectic melts - a high-pressure Variscan migmatite from northeast Sardinia. International Geology Review, 55, 1490-1505.

Ménot, R. P. \& Orsini, J. B., 1990. Evolution du socle anté-stephanien de Corse: événements magmatiques et métamorphiques. Schweizerische Mineralogische und Petrographische Mitteilungen, 70, 35-53.

Palmeri, R., Fanning, M., Franceschelli, M., Memmi, I. \& Ricci, C. A., 2004. SHRIMP dating of zircons in eclogite from the Variscan basement in north-eastern Sardinia (Italy). Neues Jahrbuch für Mineralogie Monatshefte, 6, 275-288.

Paquette, J.-L., Ménot, R.-P., Pin, C. \& Orsini, J.-B., 2003. Episodic and short-lived granitic pulses in a post-collisional setting: evidence from precise $\mathrm{U}-\mathrm{Pb}$ zircon dating through a crustal cross-section in Corsica. Chemical Geology, 198, 1-20.

Pitra, P. \& Guiraud, M., 1996. Probable anticlockwise P-T evolution in extending crust: Hlinsko region, Bohemian Massif. Journal of Metamorphic Geology, 14, 49-60.

Powell, R. \& Holland, T., 1999. Relating formulations of the thermodynamics of mineral 
solid solutions: Activity modeling of pyroxenes, amphiboles, and micas. American Mineralogist, 84, 1-14.

796

797

798

799

800

801

802

803

804

805

806

807

808

809

810

811

812

813

814

815

816

817

818

819

Rossi, P. \& Cocherie, A., 1991. Genesis of a Variscan batholith: field, petrological and mineralogical evidence from the Corsica-Sardinia batholith. Tectonophysics, 195, 319-346.

Rossi, P., Oggiano, G.\& Cocherie, A., 2009. A restored section of the "southern Variscan realm" across the Corsica-Sardinia microcontinent. Comptes Rendus Géoscience, $\mathbf{3 4 1}$, 224-238.

Rouire, J., Rossi, P., Bourges, F., Libourel, G. \& Dominici, R. 1993. Carte Géologique de la France $(1 / 50000)$, feuille Porto- Vecchio (1124). Notice explicative par Rouire, J., Rossi, P., Bourge, F., Libourel, G. \& Dominici, G., pp. 63. BRGM,Orleans. ISBN 27159-2124-1.

von Raumer, J.F., Finger, F., Vesel, P. \& Stampfli, G.M., 2014. Durbachites-Vaugnerites - a geodynamic marker in the central European Variscan orogen. Terra Nova, 26, 85-95.

Waizenhöfer, F. \& Massonne, H.-J., 2017. Monazite in a Variscan mylonitic paragneiss from the Münchberg Metamorphic Complex (NE Bavaria) records Cadomian protolith ages. Journal of Metamorphic Geology, in press. doi:10.1111/jmg.12240.

Wang, J.M., Zhang, J.J. \& Wang, X.X., 2013. Structural kinematics, metamorphic P-T profiles and zircon geochronology across the Greater Himalayan Crystalline Complex in south-central Tibet: implication for a revised channel flow: Journal of Metamorphic Geology, 31, 607-628.

Williams, M.L., Jercinovic, M.J. \& Hetherington, C.J., 2007. Microprobe monazite geochronology: understanding geologic processes by integrating composition and chronology. Annual Review of Earth and Planetary Sciences, 35, 137-175.

Williams, M.L., Jercinovic, M.J., Harlov, D.E., Budzyń, B. \& Hetherington, C.J., 2011. Resetting monazite ages during fluid-related alteration. Chemical Geology, 283, 218- 
821 Zeh, A., Williams, I.S., Brätz, H. \& Millar, I.L., 2003. Different age response of zircon and 822 monazite during the tectono-metamorphic evolution of a high grade paragneiss from 823 the Ruhla Crystalline Complex, central Germany. Contributions to Mineralogy and

825 Zeh, A., Holland, T.J.B. \& Klemd, R., 2005. Phase relationships in grunerite-garnet-bearing amphibolites in the system CFMASH, with applications to metamorphic rocks from

Zhou, H.-W. \& Murphy, M.A., 2005. Tomographic evidence for wholesale underthrusting of 830 India beneath the entire Tibetan plateau. Journal of Asian Earth Sciences, 25, 445-457.

831

832 


\section{Figure Captions}

834 Fig. 1. (a) Geological overview map of Corsica slightly modified after Faure et al. (2014). (b)

835 Detailed geological map of the area where micaschist sample Cors $15 \mathrm{G}$ was taken. This map 836 around the Porto Vecchio shear zone (PVSZ) was simplified after Rouire et al. (1993) and 837 Giacomini et al. (2008). The stereographic projection of structural elements is related to 838 measurements undertaken by the authors: green dots $=$ metamorphic foliation, red dots $=$ 839 mylonitic foliation, blue triangles $=$ mylonitic lineations.

Fig. 2. (a) Geological sketch map of the area at Punta di Fautea; (b) Intensely foliated medium-coarse grained micaschists and paragneisses near Punta di Fautea. The main metamorphic foliation is deformed by late assymetric folds. Length of photo: $25 \mathrm{~cm}$. (c) White mica-bearing micaschist with cm-sized euhedral garnet near Punta di Fautea. Length of photo: $20 \mathrm{~cm}$.

Fig. 3. Photomicrographs of objects in micaschist samples Cors15G (a,b,e) and Cors17 (c,d,f) seen under plane polarised light (left hand side of each image) and crossed polarisers (right hand side). $\mathrm{Bt}=$ biotite, $\mathrm{Gt}=$ garnet, $\mathrm{Mu}=$ muscovite, $\mathrm{Pl}=$ plagioclase, $\mathrm{Q}=$ quartz, $\mathrm{Si}=$

850 sillimanite. The image widths are $4 \mathrm{~mm}$ (a-d) or $0.5 \mathrm{~mm}$. (a) Older mm-sized white-mica grains surrounded by the finer-grained younger mica generation. (b) Pinite-like pseudomorph after garnet. Several small relics of garnet are still present in this pseudomorph. (c) The left hand side of the image shows a mica-rich band with several bended and kinked mica grains of the older mica generation. The upper right portion of the image is part of a quartz-feldspar band. (d) A small garnet grain in contact with a mm-sized plagioclase blast which is surrounded by smaller plagioclase grains. (e) A cluster of sillimanite (fibrolite) enveloped by an aggregate of very fine-grained mica which is surrounded by coarser-grained muscovite. (f) 
860 Fig. 4. Elemental maps of a garnet (fragment) in micaschist (a) Cors $15 \mathrm{G}$ and (b) Cors17 861 obtained with a CAMECA SX100 EMP. The scales for the colour code on the right hand side 862 of each image indicate counts of specific X-ray radiation per time unit.

Fig. 5. Results of EMP analyses of garnet in micaschist Cors15G (a) and Cors17 (b) in terms of molar fractions of grossular (+ andradite) (XCa), pyrope $(\mathrm{XMg})$, and spessartine (XMn). The solid lines show the chemical trends from the inner core to the outer mantle of garnet. The arrow of the broken line points to retrograde compositions analysed at the rim of garnet fragments formed after considerable corrosion.

Fig. 6. Elemental maps of mica clusters in micaschist (a) Cors15G and (b) Cors17 obtained with a CAMECA SX100 EMP. The scales for the colour code on the right hand side of each image indicate counts of specific X-ray radiation per time unit. Typically, large grains of the oldest mica generation are replaced by significantly finer grained micas of a later generation, which contain, for instance, lower Ti contents than the older, large grains. Abbreviations for minerals as in Figure 3.

Fig. 7. Results of EMP spot analyses of white mica in samples (a) Cors15G and (b) Cors17 in terms of Si contents ( $\mathrm{pdfu}=$ per double formula unit) versus those of diverse cations (see legend). For further information see text.

880

Fig. 8. (a) Example for a $P-T$ pseudosection calculated in this study with the computer

882 software package PERPLE_X (see text). The displayed one is for the $\mathrm{Fe}^{3+}$-free, $\mathrm{H}_{2} \mathrm{O}$-rich composition of sample Cors15G (Table 3). Abbreviations: Am = Na-rich amphibole, $\mathrm{An}=$ andalusite, $\mathrm{Bt}=$ biotite, $\mathrm{Ch}=$ chlorite, $\mathrm{Co}=$ cordierite, $\mathrm{Gt}=$ garnet, $\mathrm{Im}=$ ilmenite, $\mathrm{Kf}=\mathrm{K}$ - 
885 feldspar, $\mathrm{Lw}=$ lawsonite, $\mathrm{Om}=$ Na-rich clinopyroxene, $\mathrm{Pa}=$ paragonite, $\mathrm{Ph}=$ potassic white886 mica, $\mathrm{Pl}=$ plagioclase, $\mathrm{Q}=$ quartz, $\mathrm{Rt}=$ rutile, $\mathrm{Si}=$ sillimanite, $\mathrm{St}=$ staurolite, $\mathrm{Tt}=$ titanite, 887 Zo $=$ zoisite. $(\mathbf{b}, \mathbf{c})$ Contouring of the $P$ - $T$ pseudosection shown in (a) by isopleths for molar fractions of the garnet components grossular (+ andradite), $\mathrm{XCa}$, and pyrope, $\mathrm{XMg}$, the modal content of garnet, Gt vol\%, and the Si content (pdfu) in potassic white-mica. The bold curves mark the limits of the occurrence of garnet and potassic white-mica.

Fig. 9. (a, b) Estimates of $P-T$ conditions (error ellipses) and paths (thick lines with arrow heads) using garnet and potassic white-mica isopleths (exemplarily shown in Fig. 8). The coloured lines refer to various kinds of isopleths (green: $\mathrm{XMg}=$ molar fraction of pyrope in garnet, red: $\mathrm{XCa}=$ molar fraction of grossular+andradite in garnet, light blue: $\mathrm{XMn}=$ molar fraction of spessartine in garnet; dark yellow: modal content of garnet, blue: Si content of potassic white mica). The black lines mark the $P-T$ limits of various phases (for abbreviations see Fig. 8 and $\mathrm{Mu}=$ muscovite). The solid lines in (a) are related to the bulk-rock composition of Cors $15 \mathrm{G}$ without $\mathrm{Fe}^{3+}$ but corrected for $\mathrm{Ca}$ in apatite. The broken lines (except $P-T$ path) and the labelling in italics in this graph refer to this composition with less $\mathrm{H}_{2} \mathrm{O}$ (semi-dry in Table 3). The solid lines and grey ellipses in (b) are related to the bulk-rock composition of Cors 17 with $5 \% \mathrm{Fe}$ being trivalent and no correction for $\mathrm{Ca}$ in apatite. The broken lines (except $P-T$ path) in this graph refer to this composition but with a lower Ca content due to the apatite correction. The dashed-dotted lines and pink ellipses are related to Cors 17 without $\mathrm{Fe}^{3+}$ and apatite correction. The long axes of the ellipses mark the supposed largest error owing to P-T intersections of relevant isopleths considering a certain analytical error, for instance, in the garnet composition. (c) The solid P-T paths, which were also shown in (a) and (b), are constrained by chemically zoned garnet and other observations on micaschists Cors15G and Cors17. The broken P-T paths are less well constrained. The light grey path is 910 that from Giacomini et al. (2008) for "the paragneisses from Porto Vecchio", which considers, 
911 for instance, information from igneous rocks in the neighbourhood of the paragneisses as

912 well. Thus, we generally relate this path to the basement east and north-east of Porto Vecchio.

913

914 Fig. 10. (a) Elemental map for Y in a monazite grain of micaschist Cors15G. Cold colours 915 (blue) of the colour code mark lower counting rates than warm colours (red). (b-d) Unusual 916 large monazite grain in Cors $15 \mathrm{G}$ with significant zonation shown by a BSE image and 917 elemental maps for Y and Ce. For colour coding see (a). (e) Critical chemical parameters (see 918 legend and text) of monazite plotted versus age. Three groups were distinguished on the basis 919 of these parameters. The arbitrarily chosen limits are at $\mathrm{Y}$ contents of 6.5 and $20.3\left(\mathrm{Y}_{2} \mathrm{O}_{3} / 0.1\right.$ wt.\%). Not shown are 2 data for the $\mathrm{Th} / \mathrm{U}$ ratio which amount to 76.2 (age: $367.8 \mathrm{Ma}$ ) and 71.4 (353.6 Ma). For the given mean ages and their errors see text.

Fig. 11. Two-dimensional continent-continent collisional scenario, similar to that suggested by Massonne (2016b). (a) It considers the subduction of an oceanic plate between continental plates, with a contemporaneous supply of magmas to allow for the perpetual existence of a magmatic arc. (b) Soon after the beginning of the continent-continent collision a slab breakoff process occurs. (c,d) The subsequent process is characterized by progressive thickening of continental crust leading to an extended area of thick continental crust. The exhibited scenario is related to colliding Gondwana and Laurussia in the region of the Corsica-Sardinia block.

930 Markers (blue and yellow) represent volumes of rocks which are now exposed in the Porto 931 Vecchio area (micaschist-paragneiss sequence) and in NE Sardinia (HP migmatites). The 932 suggested timing is based on the here presented monazite ages. For further details see text. 

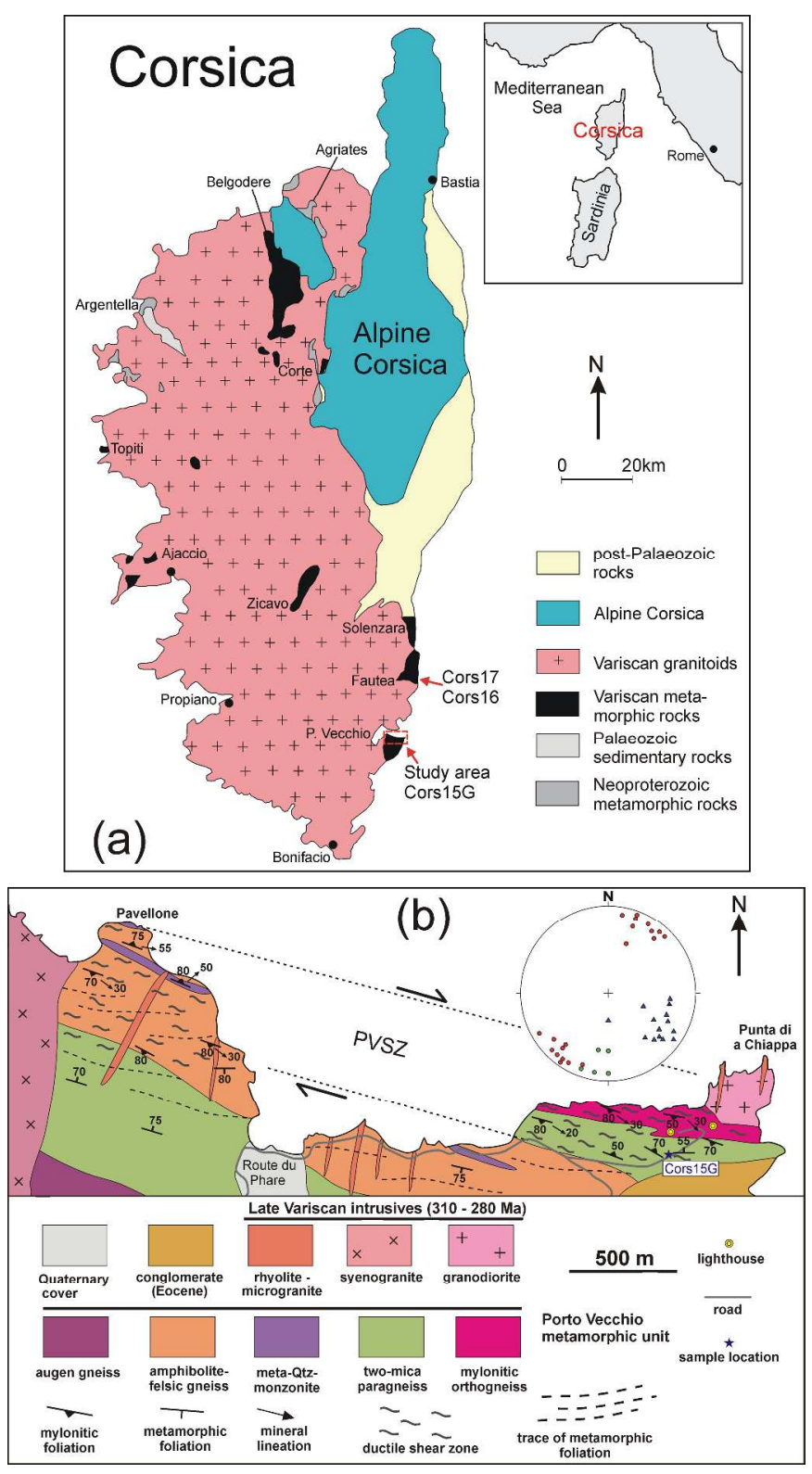

Figure 1 

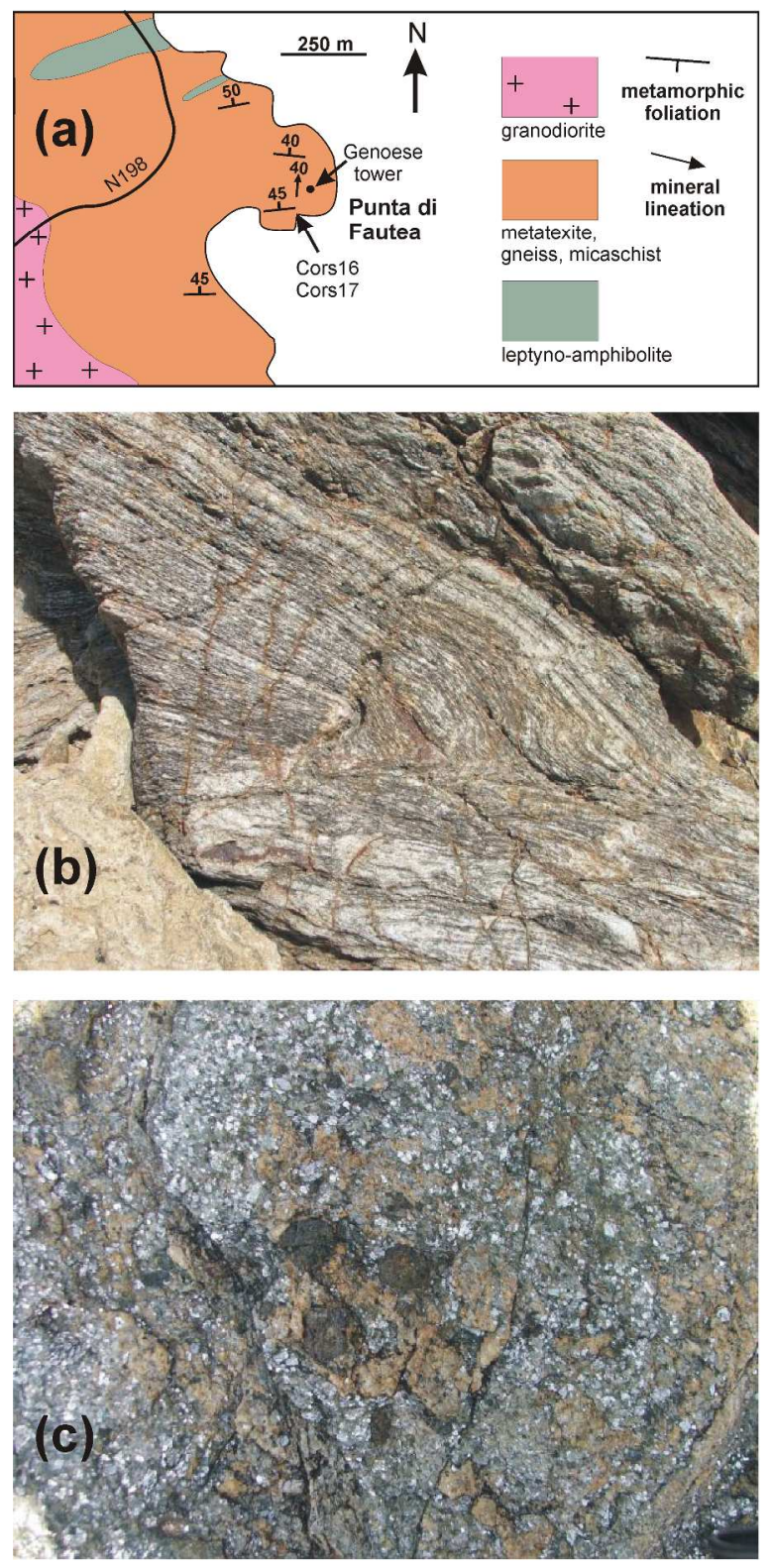

Figure 2 

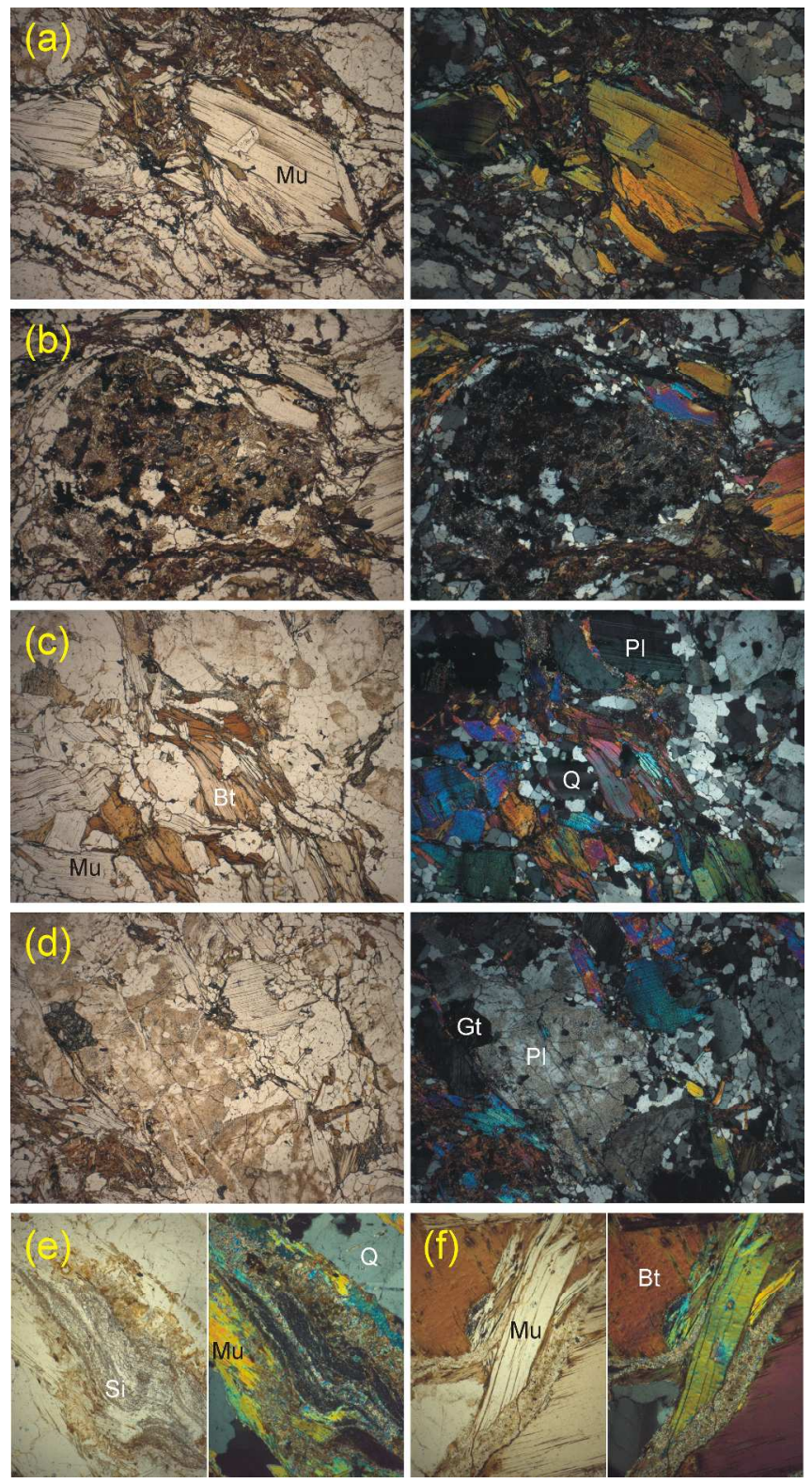

Figure 3 


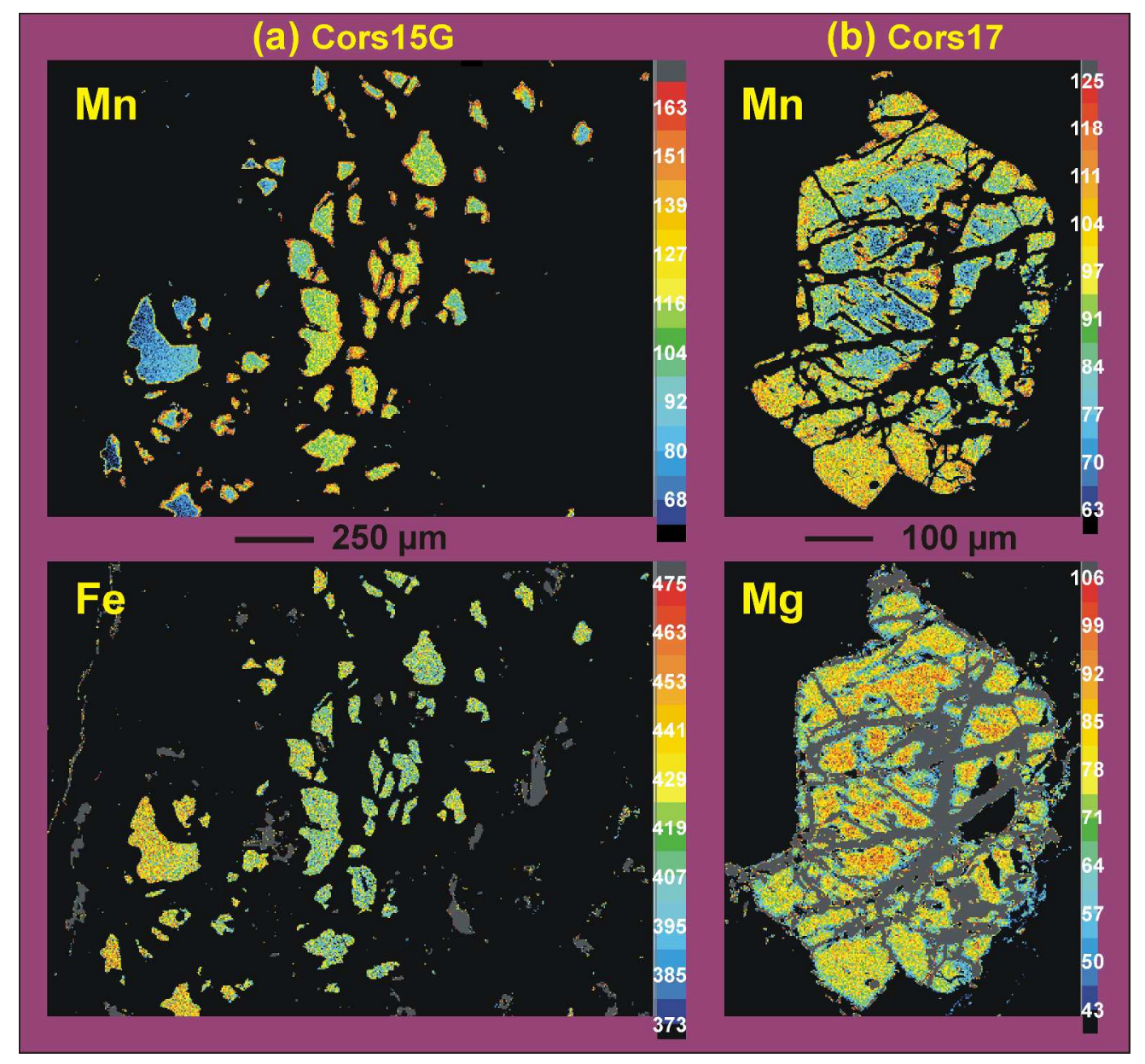

Figure 4 

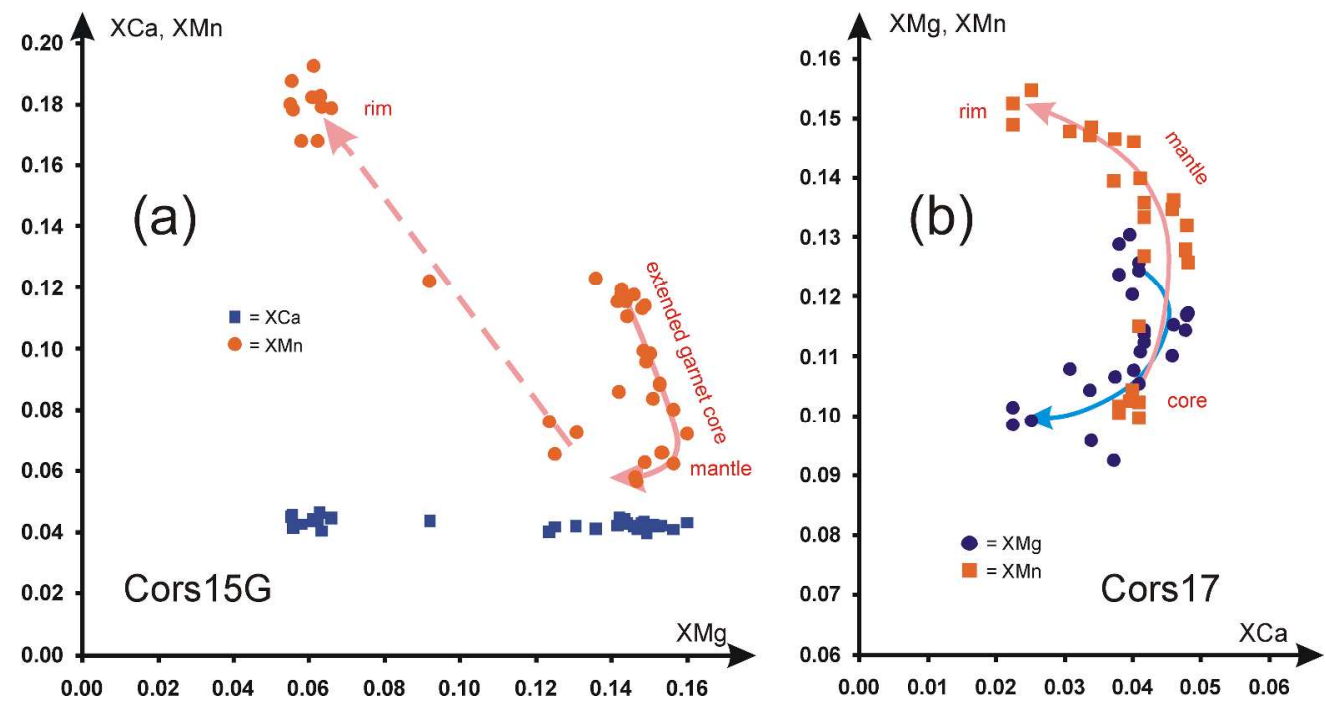

Figure 5 


\section{Page 43 of 52}

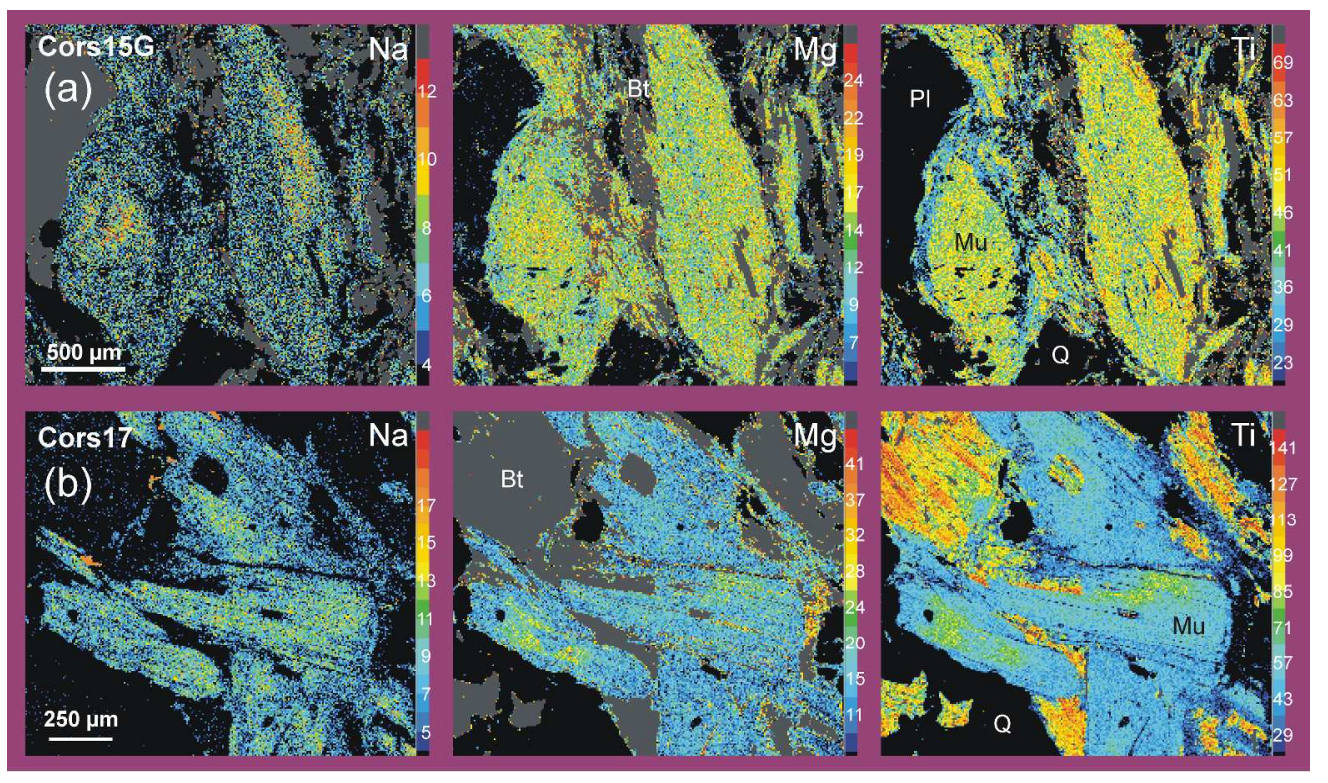

Figure 6 

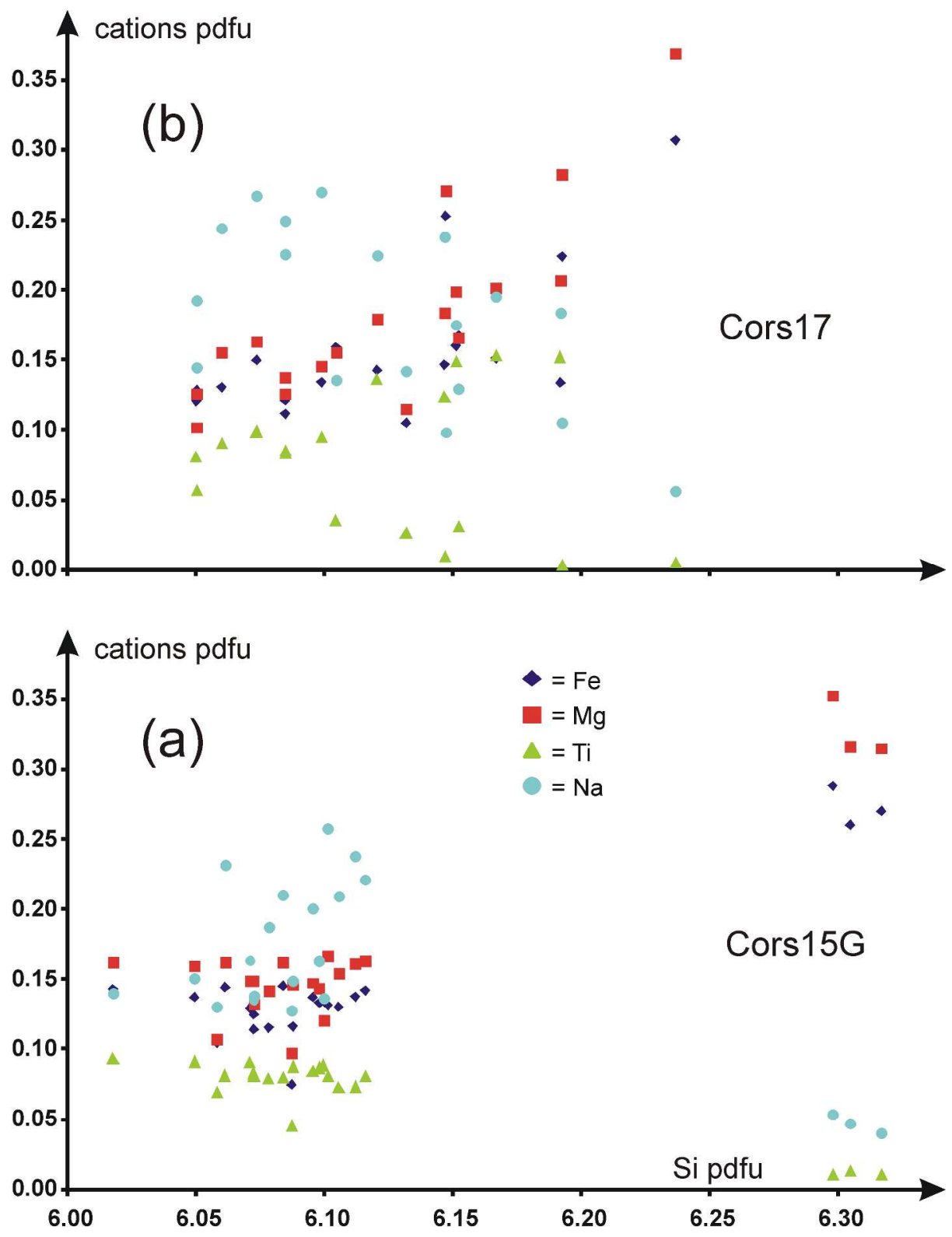

Figure 7 

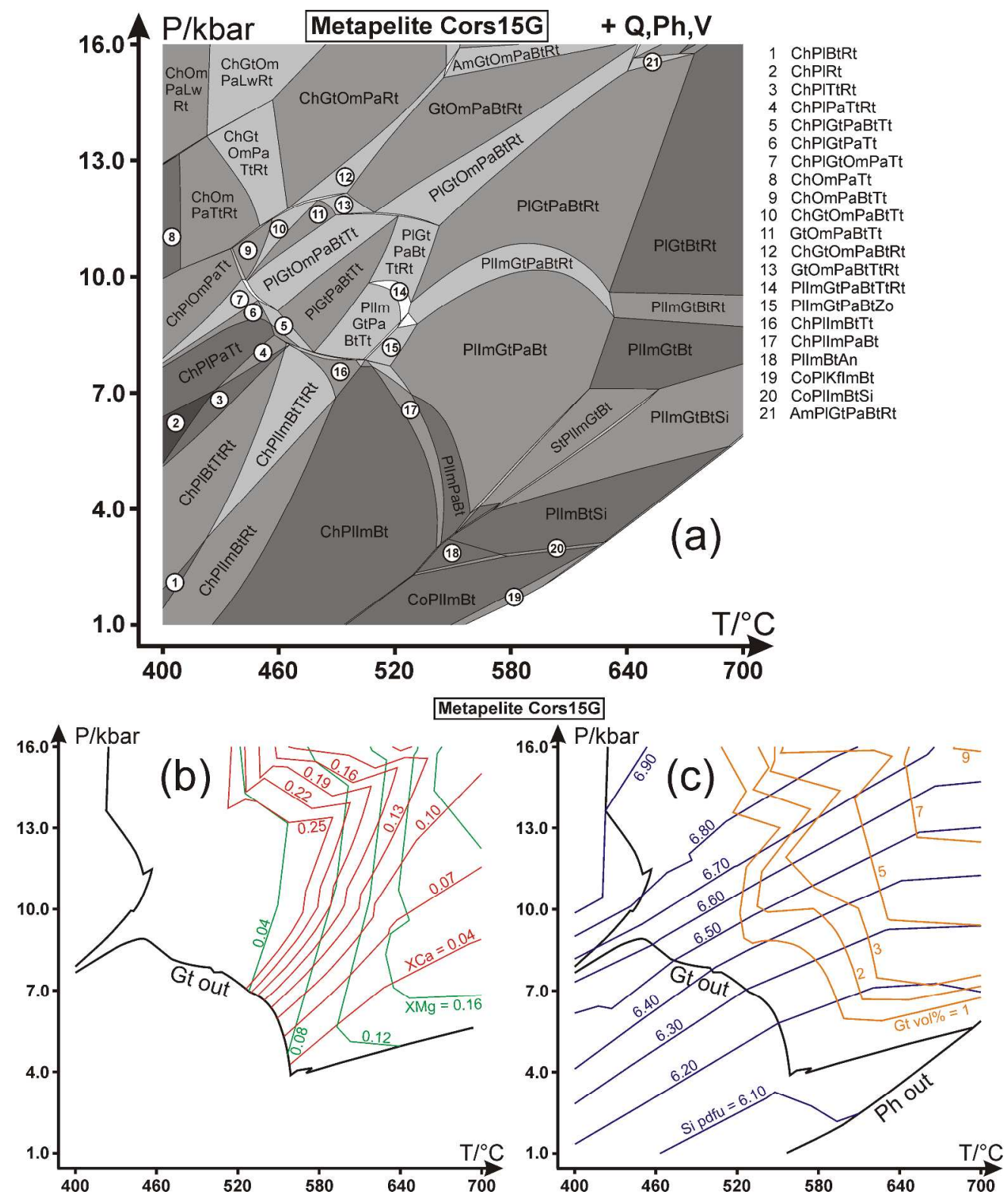

Figure 8 

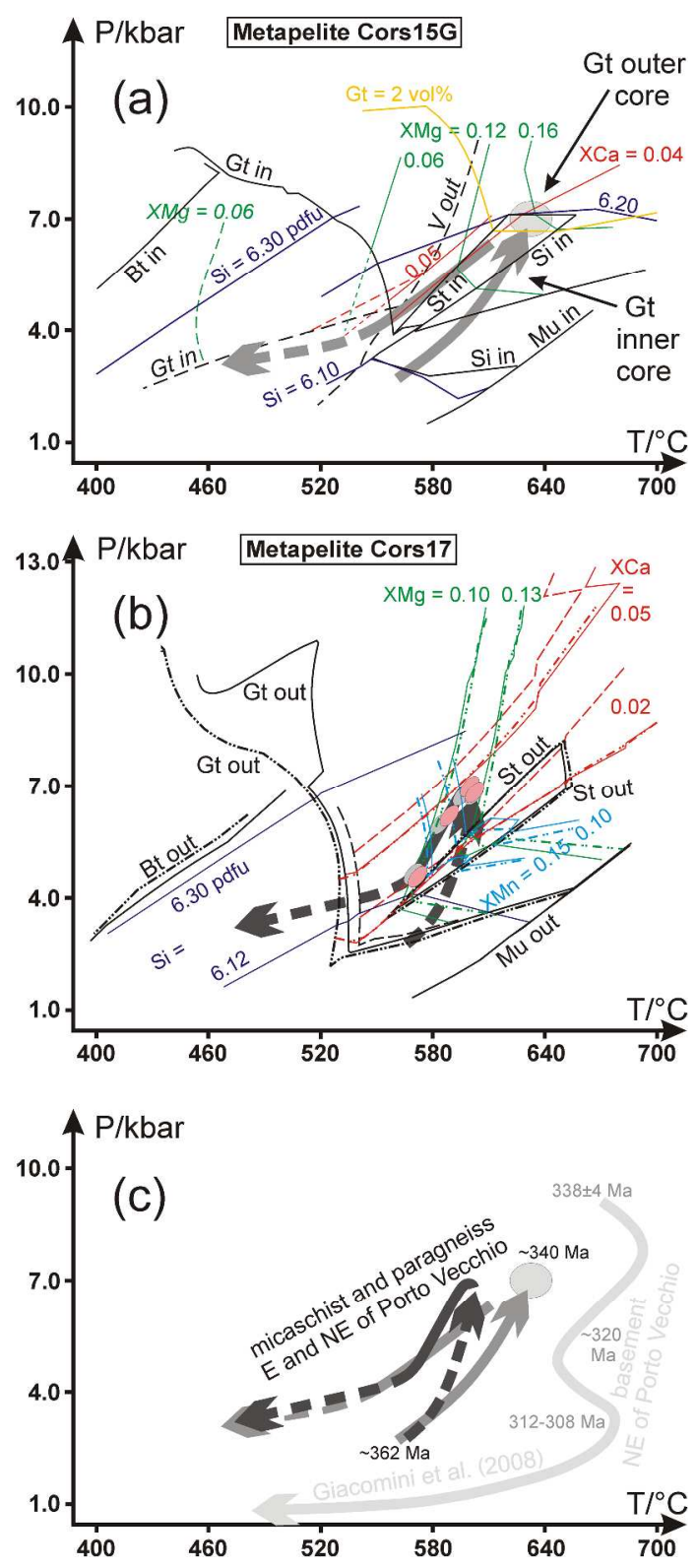

Figure 9 

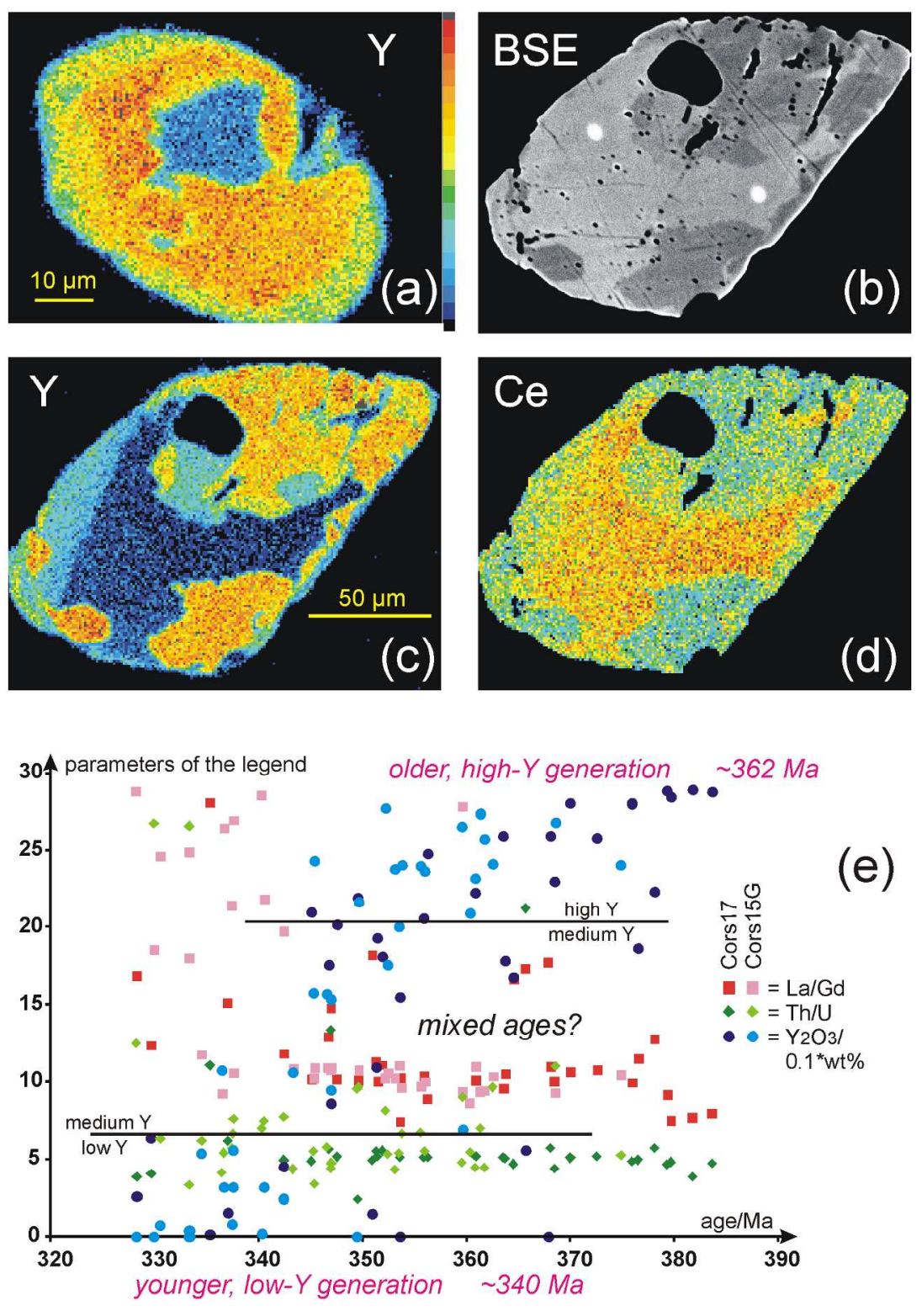

Figure 10 

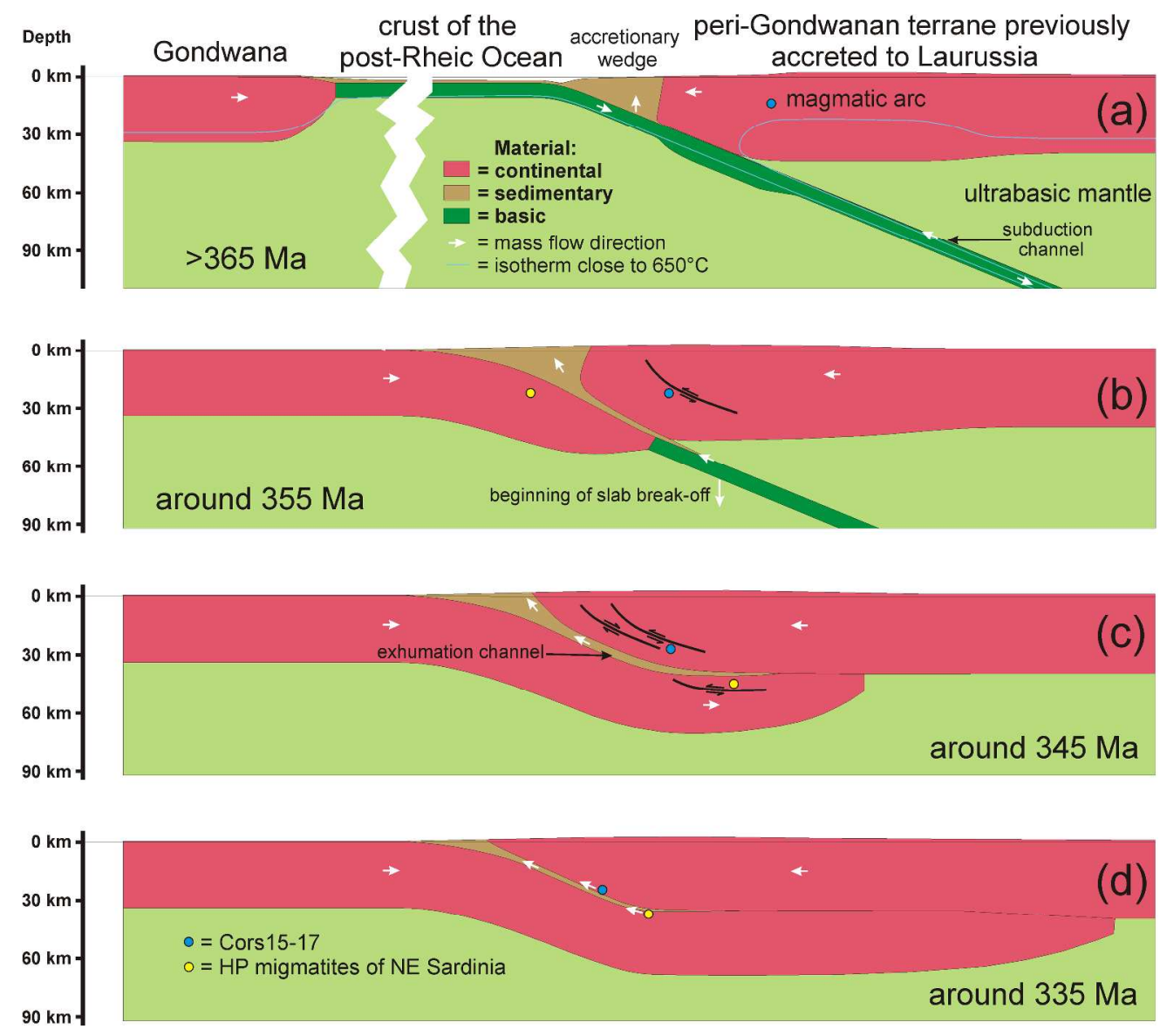

Figure 11 
Table 1. Representative analyses (in wt \%) of garnet in the studied micaschists using an EMP. Twenty-four oxygen anions (double formula unit), a cation sum of $\mathrm{Al}+\mathrm{Ca}+\mathrm{Cr}+\mathrm{Fe}+\mathrm{Mg}+$ $\mathrm{Mn}+\mathrm{Na}=10$, and the relation $\mathrm{Fe}^{3+}=4-(\mathrm{Al}+\mathrm{Cr})$ were considered to calculate the structural formula of garnet. i. $=$ inner, o. $=$ outer, $\mathrm{XFe}^{2+}, \mathrm{XCa}, \mathrm{XMg}$, and $\mathrm{XMn}$ are molar fractions of the garnet components Alm = almandine, Gro = grossular, $\mathrm{Pyr}=$ pyrope, $\mathrm{Spe}=$ spessartine .

\begin{tabular}{|c|c|c|c|c|c|c|c|c|}
\hline sample & & Cors & & & & Cor & 17 & \\
\hline $\begin{array}{l}\text { analysis No. } \\
\text { comment }\end{array}$ & $\begin{array}{r}0312-11 \\
\text { i. core }\end{array}$ & $\begin{array}{l}0312-3 \\
\text { o. core }\end{array}$ & $\begin{array}{l}0312-1 \\
\text { mantle }\end{array}$ & $\begin{array}{r}1411-6 \\
\text { rim }\end{array}$ & $\begin{array}{r}1711-46 \\
\text { core }\end{array}$ & $\begin{array}{l}1711-54 \\
\text { i. mantle }\end{array}$ & $\begin{array}{c}1711-62 \\
\text { o. mantle }\end{array}$ & $\begin{array}{r}1711-68 \\
\text { rim }\end{array}$ \\
\hline $\mathrm{SiO}_{2}$ & 37.49 & 37.37 & 37.41 & 37.01 & 37.07 & 37.17 & 36.54 & 36.74 \\
\hline $\mathrm{TiO}_{2}$ & 0.05 & 0.01 & 0.01 & 0.05 & 0.02 & 0.00 & 0.02 & 0.00 \\
\hline $\mathrm{Al}_{2} \mathrm{O}_{3}$ & 21.39 & 21.28 & 21.49 & 21.00 & 21.06 & 21.15 & 21.11 & 21.54 \\
\hline $\mathrm{Cr}_{2} \mathrm{O}_{3}$ & 0.01 & 0.03 & 0.00 & 0.01 & 0.01 & 0.03 & 0.01 & 0.00 \\
\hline $\mathrm{Fe}_{2} \mathrm{O}_{3}$ & 0.34 & 0.76 & 0.58 & 0.06 & 0.39 & 0.31 & 0.40 & 0.00 \\
\hline $\mathrm{FeO}$ & 31.96 & 33.30 & 34.46 & 31.41 & 32.98 & 31.70 & 31.86 & 32.43 \\
\hline $\mathrm{MnO}$ & 5.21 & 3.29 & 2.87 & 8.03 & 4.56 & 5.89 & 6.52 & 6.88 \\
\hline $\mathrm{MgO}$ & 3.62 & 4.13 & 3.85 & 1.56 & 3.15 & 2.97 & 2.73 & 2.51 \\
\hline $\mathrm{CaO}$ & 1.51 & 1.56 & 1.49 & 1.62 & 1.43 & 1.68 & 1.41 & 0.88 \\
\hline $\mathrm{Na}_{2} \mathrm{O}$ & 0.03 & 0.03 & 0.03 & 0.04 & 0.00 & 0.03 & 0.02 & 0.01 \\
\hline Total & 101.63 & 101.75 & 102.20 & 100.79 & 100.65 & 100.94 & 100.62 & 101.00 \\
\hline $\mathrm{Si}$ & 5.885 & 5.821 & 5.808 & 5.969 & 5.904 & 5.904 & 5.804 & 5.826 \\
\hline $\mathrm{Ti}$ & 0.006 & 0.001 & 0.002 & 0.005 & 0.002 & 0.000 & 0.002 & 0.000 \\
\hline $\mathrm{Al}$ & 3.958 & 3.908 & 3.932 & 3.991 & 3.953 & 3.959 & 3.951 & 4.027 \\
\hline $\mathrm{Cr}$ & 0.002 & 0.003 & 0.000 & 0.002 & 0.001 & 0.003 & 0.002 & 0.000 \\
\hline $\mathrm{Fe}^{3+}$ & 0.040 & 0.089 & 0.067 & 0.008 & 0.046 & 0.037 & 0.047 & 0.000 \\
\hline $\mathrm{Fe}^{2+}$ & 4.196 & 4.339 & 4.474 & 4.235 & 4.394 & 4.211 & 4.231 & 4.301 \\
\hline Mg & 0.848 & 0.958 & 0.892 & 0.376 & 0.747 & 0.702 & 0.647 & 0.593 \\
\hline Mn & 0.693 & 0.434 & 0.378 & 1.097 & 0.615 & 0.793 & 0.877 & 0.924 \\
\hline $\mathrm{Ca}$ & 0.255 & 0.260 & 0.249 & 0.279 & 0.244 & 0.286 & 0.240 & 0.150 \\
\hline $\mathrm{Na}$ & 0.008 & 0.009 & 0.008 & 0.013 & 0.000 & 0.008 & 0.005 & 0.005 \\
\hline $\mathrm{Alm}=\mathrm{XFe} \mathrm{e}^{2+}$ & 0.6993 & 0.7231 & 0.7456 & 0.7059 & 0.7323 & 0.7018 & 0.7052 & 0.7200 \\
\hline Gro $=\mathrm{XCa}$ & 0.0424 & 0.0433 & 0.0414 & 0.0465 & 0.0407 & 0.0477 & 0.0399 & 0.0251 \\
\hline Pyr $=X M g$ & 0.1413 & 0.1597 & 0.1486 & 0.0626 & 0.1245 & 0.1171 & 0.1078 & 0.0993 \\
\hline Spe $=X M n$ & 0.1155 & 0.0723 & 0.0630 & 0.1828 & 0.1025 & 0.1321 & 0.1462 & 0.1548 \\
\hline
\end{tabular}


Table 2. Representative analyses (in wt \%) of diverse minerals in the studied micaschists using an EMP. The total was corrected for F. The structural formulae of the minerals were calculated as follows: muscovite (double formula unit) $=22-(1+\mathrm{Ca}+\mathrm{Ba}) \mathrm{O}$ and (to calculate $\mathrm{Fe}^{3+}$ ) $\mathrm{Si}+\mathrm{Ti}+\mathrm{Al}+\mathrm{Fe}+\mathrm{Mn}+\mathrm{Mg} \leq 4.10$ (see Massonne \& Schreyer, 1986); biotite $=11 \mathrm{O}$; feldspar $=8 \mathrm{O}$; sillimanite $=3$ cations. $\mathrm{H}_{2} \mathrm{O}$ was calculated.

\section{$\mathrm{F}$ \\ Si \\ $\mathrm{Al}$ \\ $\mathrm{Ti}$ \\ $\mathrm{Cr}$
$\mathrm{Fe}^{2+}$ \\ $\mathrm{Mn}$ \\ $\mathrm{Mg}$ \\ $\mathrm{Ca}$ \\ $\mathrm{Ba}$ \\ $\mathrm{Na}$ \\ $\mathrm{K}$ \\ F \\ $\mathrm{H}$}

sample

mineral

analysis No.

comment

muscovite

2611-64 2611-51

large very small

$\mathrm{SiO}_{2}$

$\mathrm{TiO}_{2}$

$\mathrm{Al}_{2} \mathrm{O}_{3}$

$\mathrm{Cr}_{2} \mathrm{O}_{3}$

$\mathrm{FeO}$

$\mathrm{Fe}_{2} \mathrm{O}_{3}$

$\mathrm{MnO}$

$\mathrm{MgO}$

$\mathrm{CaO}$

$\mathrm{Na}_{2} \mathrm{O}$

$\mathrm{K}_{2} \mathrm{O}$

$\mathrm{BaO}$

$\mathrm{H}_{2} \mathrm{O}$

Total

$\mathrm{Fe}^{3+}$

$0.87 \quad 0.13$

$35.51 \quad 33.19$

$1.04 \quad 2.35$

$0.00 \quad 0.00$

$0.02 \quad 0.07$

$0.73 \quad 1.60$

$0.01 \quad 0.10$

$0.58 \quad 0.18$

$10.97 \quad 10.45$

$0.34 \quad 0.13$

$0.08 \quad 0.07$

$\begin{array}{rr}4.45 & 4.49\end{array}$

$100.16 \quad 100.28$

$5.590 \quad 5.186$

$0.087 \quad 0.013$

$0.116 \quad 0.260$

$0.000 \quad 0.000$

$0.003 \quad 0.008$

$0.146 \quad 0.317$

$0.001 \quad 0.014$

$0.018 \quad 0.007$

$1.870 \quad 1.768$

$0.032 \quad 0.031$

$3.968 \quad 3.969$

\section{Cors15G}

biotite plagioclase sillimanite 2611-59

$45.58 \quad 47.55$

$6.088 \quad 6.305$

$0.149 \quad 0.047$

$$
\text { 2611-53 1411-18 }
$$

$\begin{array}{rrr}34.41 & 62.81 & 37.35 \\ 2.69 & 0.00 & 0.00 \\ 20.30 & 23.68 & 63.20 \\ & & 0.04 \\ 21.30 & & \\ & 0.02 & 0.15 \\ 0.26 & 0.00 & 0.00\end{array}$

7.40

0.00

0.16

9.84

0.13

0.05

3.91
100.43

100.43

2.623

1.824

0.154

1.358

0.017

0.841

0.000

0.004

0.023

0.957

0.012

1.988
4.57

8.92

0.39

0.00

100.40

100.75

$2.771 \quad 1.001$

1.231

0.000

1.995

0.000

0.001

$0.001 \quad 0.003$

0.000

\subsection{6}

0.000

0.763

0.022

\begin{tabular}{rr}
\multicolumn{2}{c}{ muscovite } \\
$2611-16$ & $2611-3$ \\
Ti-rich & Ti-poor \\
& \\
& \\
45.50 & 46.49 \\
0.83 & 0.03 \\
35.62 & 34.38 \\
& \\
1.00 & 1.99 \\
0.00 & 0.03 \\
0.03 & 0.00 \\
0.63 & 1.42 \\
0.00 & 0.01 \\
0.87 & 0.41 \\
10.31 & 10.64 \\
0.26 & 0.14 \\
0.13 & 0.00 \\
4.42 & 4.50 \\
99.54 & 100.04 \\
& \\
6.085 & 6.193 \\
5.615 & 5.397 \\
0.084 & 0.003 \\
& \\
0.112 & 0.222 \\
0.000 & 0.003 \\
0.004 & 0.000 \\
0.125 & 0.283 \\
0.000 & 0.002 \\
0.013 & 0.007 \\
0.226 & 0.105 \\
1.758 & 1.807 \\
0.055 & 0.000 \\
3.945 & 4.000
\end{tabular}

\section{Cors17}

\begin{tabular}{|c|c|c|c|}
\hline biotite & & plagioclase & K-feldspar \\
\hline $2611-18$ & $2611-21$ & 2611-34 & $2611-8$ \\
\hline Ti-rich & Ti-poor & & \\
\hline 34.65 & 35.11 & 64.55 & 63.49 \\
\hline 2.42 & 1.04 & 0.00 & 0.02 \\
\hline 19.58 & 20.88 & 22.78 & 18.18 \\
\hline 21.38 & 20.95 & & \\
\hline & & 0.01 & 0.38 \\
\hline 0.23 & 0.15 & 0.00 & 0.00 \\
\hline 8.33 & 8.67 & & \\
\hline 0.01 & 0.00 & 3.41 & 0.00 \\
\hline 0.09 & 0.14 & 9.62 & 0.11 \\
\hline 9.25 & 9.50 & 0.23 & 16.70 \\
\hline 0.06 & 0.05 & 0.00 & 1.05 \\
\hline 0.13 & 0.19 & & \\
\hline 3.87 & 3.88 & & \\
\hline 99.94 & 100.48 & 100.61 & 99.93 \\
\hline 2.646 & 2.655 & 2.829 & 2.975 \\
\hline 1.762 & 1.404 & 1.177 & 1.004 \\
\hline 0.139 & 0.515 & 0.000 & 0.001 \\
\hline 1.365 & 1.325 & & \\
\hline & & 0.000 & 0.013 \\
\hline 0.015 & 0.010 & 0.000 & 0.000 \\
\hline 0.948 & 0.977 & & \\
\hline 0.001 & 0.000 & 0.160 & 0.000 \\
\hline 0.002 & 0.021 & 0.000 & 0.019 \\
\hline 0.014 & 0.917 & 0.817 & 0.010 \\
\hline 0.901 & 0.001 & 0.013 & 0.998 \\
\hline 0.031 & 0.045 & & \\
\hline
\end{tabular}


Table 3. Bulk-rock composition (in wt $\%$ ) of micaschists from south-eastern Corsica determined with wavelength-dispersive X-ray fluorescence (XRF) spectrometry. Slightly modified compositions used for thermodynamic calculations with PERPLE_X are given. 0 or $5 \%$ of Fe is trivalent. Reduction of the $\mathrm{CaO}$ content, corresponding to two third of the phosphorus content being related to form apatite (Ap), is marked by $2 / 3$ Ap. The "semi-dry" composition results in water undersaturated conditions during retrogression.

\section{Sample}

Comment

$\mathrm{SiO}_{2}$
$\mathrm{TiO}_{2}$
$\mathrm{Al}_{2} \mathrm{O}_{3}$
$\mathrm{FeO}$
$\mathrm{Fe}_{2} \mathrm{O}_{3}$ or $\mathrm{O}_{2}$
$\mathrm{MnO}$
$\mathrm{MgO}$
$\mathrm{CaO}$
$\mathrm{Na}{ }_{2} \mathrm{O}$
$\mathrm{K}_{2} \mathrm{O}$
$\mathrm{H}_{2} \mathrm{O}$
$\mathrm{P}_{2} \mathrm{O}_{5}$

SUM

XRF


66.131
0.710
17.328

5.276
0.062
1.759
0.802
1.753
4.393

0.150

98.364

\section{Cors15G}

modified for PERPLE_X calculations $0 \% \mathrm{Fe}^{3+}, 2 / 3 \mathrm{Ap} \quad 5 \% \mathrm{Fe}^{3+}, 2 / 3 \mathrm{Ap}$ semi-dry

$\begin{array}{rrr}64.400 & 64.382 & 66.467 \\ 0.691 & 0.691 & 0.714 \\ 16.874 & 16.870 & 17.416 \\ 4.623 & 4.622 & 4.772 \\ & 0.026 & \\ 0.060 & 0.060 & 0.062 \\ 1.713 & 1.712 & 1.768 \\ 0.653 & 0.653 & 0.674 \\ 1.707 & 1.707 & 1.762 \\ 4.278 & 4.277 & 4.415 \\ 5.000 & 5.000 & 1.950 \\ & & \\ 100.000 & 100.000 & 100.000\end{array}$

Cors16 XRF

60.386
0.882
22.576
6.195
0.124
1.446
0.187
0.953
4.407

0.063

97.219

\section{Cors17}

XRF

modified for PERPLE_X calculations $0 \% \mathrm{Fe}^{3+}$,no Ap $5 \% \mathrm{Fe}^{3+}, 2 / 3 \mathrm{Ap} \quad 5 \% \mathrm{Fe}^{3+}$,no Ap

69.882
0.645
15.631

4.998
0.098
1.601
0.468
1.898
3.296
0.097

67.731

0.625

15.150

4.359

0.095

1.552

0.454

1.840

3.195

5.000

98.614

100.000
67.714 0.625

15.146

4.358

0.024

0.095

1.551

0.453

1.839

3.194

5.000

100.000 
Table 4. Representative EMP analyses (in wt $\%$ ) of monazite in micaschist samples Cors15G and Cors17. The structural formula of monazite is related to $4 \mathrm{O}$.

\begin{tabular}{|c|c|c|c|c|}
\hline Sample & \multicolumn{2}{|c|}{ Cors15G } & \multicolumn{2}{|c|}{ Cors17 } \\
\hline Grain & 12 & 16 & 2 & 11 \\
\hline Analysis No. & 58 & 65 & 3 & 22 \\
\hline $\mathrm{SiO}_{2}$ & 0.17 & 0.55 & 0.12 & 0.26 \\
\hline $\mathrm{P}_{2} \mathrm{O}_{5}$ & 28.69 & 27.74 & 28.59 & 28.28 \\
\hline $\mathrm{SO}_{3}$ & 0.02 & 0.02 & 0.02 & 0.02 \\
\hline $\mathrm{CaO}$ & 1.07 & 1.02 & 1.05 & 0.95 \\
\hline $\mathrm{Y}_{2} \mathrm{O}_{3}$ & 2.68 & 0.02 & 2.59 & 0.15 \\
\hline $\mathrm{La}_{2} \mathrm{O}_{3}$ & 13.34 & 15.52 & 13.22 & 14.20 \\
\hline $\mathrm{Ce}_{2} \mathrm{O}_{3}$ & 27.53 & 29.35 & 27.87 & 30.14 \\
\hline $\mathrm{Pr}_{2} \mathrm{O}_{3}$ & 2.94 & 3.02 & 2.92 & 3.14 \\
\hline $\mathrm{Nd}_{2} \mathrm{O}_{3}$ & 11.07 & 10.98 & 10.98 & 12.04 \\
\hline $\mathrm{Sm}_{2} \mathrm{O}_{3}$ & 1.81 & 1.56 & 1.84 & 2.18 \\
\hline $\mathrm{Gd}_{2} \mathrm{O}_{3}$ & 1.59 & 0.60 & 1.54 & 1.04 \\
\hline $\mathrm{Dy}_{2} \mathrm{O}_{3}$ & 0.84 & 0.10 & 0.80 & 0.20 \\
\hline $\mathrm{Er}_{2} \mathrm{O}_{3}$ & 0.23 & 0.04 & 0.24 & 0.04 \\
\hline $\mathrm{PbO}$ & 0.1046 & 0.1367 & 0.1187 & 0.0980 \\
\hline $\mathrm{ThO}_{2}$ & 5.16 & 6.44 & 4.70 & 4.47 \\
\hline $\mathrm{UO}_{2}$ & 0.48 & 0.94 & 0.93 & 0.74 \\
\hline Sum & 97.73 & 98.02 & 97.52 & 97.95 \\
\hline Si & 0.0068 & 0.0226 & 0.0049 & 0.0104 \\
\hline P & 0.9788 & 0.9612 & 0.9791 & 0.9746 \\
\hline$S$ & 0.0006 & 0.0005 & 0.0006 & 0.0005 \\
\hline $\mathrm{Ca}$ & 0.0463 & 0.0445 & 0.0454 & 0.0415 \\
\hline$Y$ & 0.0575 & 0.0003 & 0.0557 & 0.0033 \\
\hline La & 0.1982 & 0.2342 & 0.1973 & 0.2131 \\
\hline $\mathrm{Ce}$ & 0.4061 & 0.4396 & 0.4127 & 0.4491 \\
\hline $\mathrm{Pr}$ & 0.0432 & 0.0450 & 0.0430 & 0.0465 \\
\hline $\mathrm{Nd}$ & 0.1593 & 0.1605 & 0.1586 & 0.1750 \\
\hline $\mathrm{Sm}$ & 0.0252 & 0.0219 & 0.0257 & 0.0306 \\
\hline $\mathrm{Gd}$ & 0.0213 & 0.0082 & 0.0207 & 0.0141 \\
\hline Dy & 0.0110 & 0.0013 & 0.0104 & 0.0026 \\
\hline $\mathrm{Er}$ & 0.0029 & 0.0005 & 0.0030 & 0.0005 \\
\hline $\mathrm{Pb}$ & 0.0011 & 0.0015 & 0.0013 & 0.0011 \\
\hline Th & 0.0474 & 0.0600 & 0.0432 & 0.0414 \\
\hline$U$ & 0.0043 & 0.0086 & 0.0084 & 0.0067 \\
\hline Age (Ma) & 368.6 & 340.3 & 363.5 & 337.0 \\
\hline $1 \sigma$ error & 7.2 & 5.2 & 6.3 & 6.9 \\
\hline
\end{tabular}

